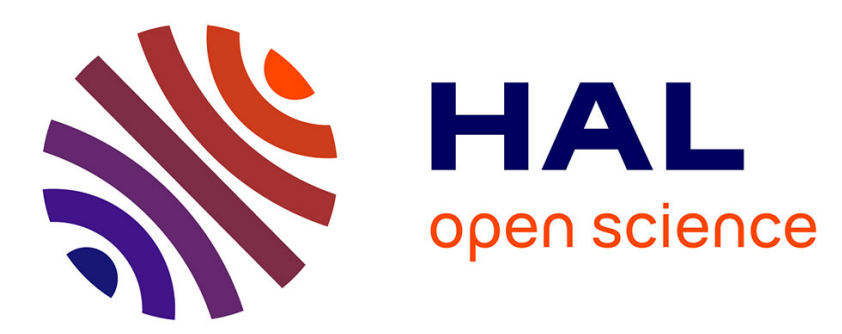

\title{
Cav2.1 C-terminal fragments produced in Xenopus laevis oocytes do not modify the channel expression and functional properties
}

Claudine Ménard, Pierre Charnet, Matthieu Rousset, Michel Vignes, Thierry Cens

\section{To cite this version:}

Claudine Ménard, Pierre Charnet, Matthieu Rousset, Michel Vignes, Thierry Cens. Cav2.1 C-terminal fragments produced in Xenopus laevis oocytes do not modify the channel expression and functional properties. European Journal of Neuroscience, 2020, 10.1111/ejn.14685 hal-02458389

\section{HAL Id: hal-02458389 \\ https://hal.science/hal-02458389}

Submitted on 28 Jan 2020

HAL is a multi-disciplinary open access archive for the deposit and dissemination of scientific research documents, whether they are published or not. The documents may come from teaching and research institutions in France or abroad, or from public or private research centers.
L'archive ouverte pluridisciplinaire HAL, est destinée au dépôt et à la diffusion de documents scientifiques de niveau recherche, publiés ou non, émanant des établissements d'enseignement et de recherche français ou étrangers, des laboratoires publics ou privés. 
Research report

Journal Section: Molecular and Synaptic Mechanisms

Cav2.1 C-terminal fragments produced in Xenopus laevis oocytes do not modify the channel expression and functional properties

Claudine Ménard, Pierre Charnet, Matthieu Rousset, Michel Vignes and Thierry Cens

Institut des Biomolécules Max Mousseron (IBMM), CNRS UMR 5247, Place Eugène Bataillon, 34095 Montpellier cedex 5, France. Université de Montpellier, Place Eugène Bataillon, 34095 Montpellier cedex 5, France.

Corresponding author: Thierry Cens, Université de Montpellier, Case courrier 0090, Place Eugène Bataillon, 34095 Montpellier cedex 5, E-mail address: thierry.cens@inserm.fr.

Running title: Cav2.1 and its C-terminal fragments in $X$. laevis oocytes

Total number of pages: 30

Total number of figures: 6

Total number of tables: 1

Total number of equations: 2

Total number of words in the whole manuscript: 7621

Total number of words in the abstract: 225

Keywords (maximum of 6 keywords): $\mathrm{Ca}^{2+}$ channel, Xenopus laevis oocytes, electrophysiology, co-immunoprecipitation assay 
Abstract

The sequence and genomic organization of the CACNA1A gene that encodes the Cav2.1 subunit of both $\mathrm{P}$ and $\mathrm{Q}$ type $\mathrm{Ca} 2^{+}$channels are well conserved in mammals. In human, rat and mouse CACNA1A, the use of an alternative acceptor site at the exon 46-47 boundary results in the expression of a long Cav2.1 splice variant. In transfected cells, the long isoform of human Cav2.1 produces a C-terminal fragment, but it is not known whether this fragment affects Cav2.1 expression or functional properties. Here, we cloned the long isoform of rat Cav2.1 (Cav2.1(e47)) and identified a novel variant with a shorter C-terminus (Cav2.1(e47s)) that differs from those previously described in the rat and mouse. When expressed in Xenopus laevis oocytes, Cav2.1(e47) and Cav2.1(e47s) displayed similar functional properties as the short isoform (Cav2.1). We show that Cav2.1 isoforms produced short (CT1) and long (CT1(e47)) C-terminal fragments that interacted in vivo with the auxiliary Cav $\beta 4$ a subunit. Overexpression of the C-terminal fragments did not affect Cav2.1 expression and functional properties. Furthermore, the functional properties of a Cav2.1 mutant without the C-terminal Cav $\beta 4$ binding domain (Cav2.1 $\triangle \mathrm{CT} 2)$ were similar to those of Cav2.1, and were not influenced by the co-expression of the missing fragments (CT2 or CT2(e47)). Our results exclude a functional role of the C-terminal fragments in Cav2.1 biophysical properties in an expression system widely used to study this channel. 


\section{INTRODUCTION}

Voltage gated $\mathrm{Ca}^{2+}$ channels are heteromultimeric assemblies of the pore-forming Cav $\alpha 1$ subunit and of the auxiliary subunits $\operatorname{Cav} \beta$ and $\operatorname{Cav} \alpha 2 \delta$. The human genome contains ten genes encoding Cava1 subunits (Cav1.1 to 1.4, Cav2.1 to 2.3 and Cav3.1 to 3.3), four genes encoding $\operatorname{Cav} \beta$ subunits (Cav $\beta 1-4)$, and four genes encoding Cav $\alpha 2 \delta$ subunits (Cav $\alpha 2 \delta 1-4)$. The interactions between Cav $\alpha 1$ and its auxiliary subunits determine the channel expression level and functional properties (Buraei \& Yang, 2010). The Cav2.1 subunit is the pore-forming subunit of the P- and Q-type $\mathrm{Ca}^{2+}$ channels (Pinto et al., 1998; Jun et al., 1999) that are widely expressed in the central nervous system, particularly in the cerebellum where they were first described (Mintz et al., 1992; McDonough et al., 1996). The pharmacological and functional properties that differentiate P- from Q-type channels result from alternative splicing of the Cav2.1 subunit and specific co-expression of one auxiliary Cav $\beta$ subunit (Hans et al., 1999; Kanumilli et al., 2006). C-terminal Cav2.1 variants are created by insertion/omission of the GGCAG sequence at the beginning of exon 47 (Fig. 1). However, this insertion is not the only event that diversifies the C-terminal extremity of Cav2.1. Specifically, the rabbit BI-1 variant lacks the GGCAG insertion, but harbors a sequence closely related to that found in human exon 47 (Andrés-Mateos et al., 2006). Conversely, the rabbit BI-2 variant results from the removal of the exon 46 end and the first third of exon 47 (Mori et al., 1991). Similar recombination events have also been described in the human CACNA1A gene, although they lead to isoforms that are completely different from BI-2 (Zhuchenko et al., 1997; Veneziano et al., 2009). A mouse isoform with a fully translated exon 47 , similar to the human sequence, has been described (Richards et al., 2007), but other isoforms also exist. For instance, MPII (BAB85612) results from the use of an alternative acceptor site at the beginning of exon 47 (Fig. 1) that leads to the expression of a unique sequence up to the deletion of a single base allowing the recovery of the original reading frame of the fully translated exon 47 . Therefore, MPII C-terminus is 
close to that of the human subunit (Tsunemi et al., 2002). In the MPI isoform (BAB85611), deletion of 150 nucleotides in exon 47 produces a translational frameshift, leading to a specific C-terminal sequence (Tsunemi et al., 2002). Given the high degree of sequence conservation in Cav2.1 and the similarities in the CACNA1 gene organization in different species (Soong et al., 2002; Kanumilli et al., 2006), such variability in the Cav2.1 C-terminus is quite intriguing. Moreover, it is not clear whether and how these specific sequences affect the functional properties of Cav2.1 channels.

Interestingly, when the human Cav2.1 subunit is expressed in HEK cells, a $60-75 \mathrm{kDa}$ fragment $(\alpha 1 \mathrm{ACT})$ that contains a tract of glutamine residues (polyQ) can be detected in cell nuclei with antibodies against the Cava1 C-terminus (Kubodera et al., 2003; Kordasiewicz et al., 2006). The $\alpha 1$ ACT protein is translated through an internal ribosome entry site (IRES) located within the mature mRNA encoding the Cav2.1 subunit (Du et al., 2013), and may act as a transcription factor that modulates the expression of genes involved in neural development (Du et al., 2013). Importantly, $\alpha 1 \mathrm{ACT}$ harboring a pathologic polyQ expansion, as observed in spinocerebellar ataxia type 6 (SCA6), cannot upregulate these genes (Du et al., 2013; Ishida et al., 2016; Bavassano et al., 2017). SCA6 is an autosomal dominant cerebellar ataxia caused by expansion of this polyQ tract and characterized by the formation of insoluble aggregates in cerebellar Purkinje cells. Due to alternative splicing, the polyQ expansion is present in the Cav2.1 subunit with an extended C-terminus, but not in the short isoforms (Zhuchenko et al., 1997). Studies on the functional impact of the pathological polyQ expansion in Cav2.1 gave rise to discrepancies, probably due to differences in the used Cav2.1 isoforms and/or cell lines (Matsuyama et al., 1999; Restituito et al., 2000; Toru et al., 2000; Piedras-Renteria et al., 2001). However, the functional properties of human Cav2.1 harboring a pathological polyQ expansion are not affected in Purkinje cells isolated from a knock-in mouse model of SCA6 (Saegusa et al., 2007). 
Unlike many other species, the rat and mouse Cacna1a genes are devoid of CAG repeats (Andrés-Mateos et al., 2006), thus precluding the additional level of complexity of $\alpha 1 \mathrm{ACT}$ functions brought by the polyQ expansion. Rat Cav2.1 with an extended C-terminus encoded by exon 47 (called herein Cav2.1(e47)) (Fig. 1) has not been functionally characterized yet and only the short variant Cav2.1 (called herein Cav2.1) is currently available for functional studies. Therefore, here we used Xenopus laevis oocytes, a heterologous expression system that has been used to study Cav2.1 calcium channels for nearly three decades, to determine whether a similar C-terminal fragment is produced also in oocytes that express rat Cav2.1, and whether co-expression of this fragment and Cav2.1 affects the channel properties. Indeed, Cava1 Cterminus interacts with the Cav $\beta 4$ subunits or other regions of the Cav $\alpha$ subunit (Sandoz et al., 2001; Geib et al., 2002). To this aim, we cloned a novel variant of the extended rat Cav2.1 Cterminus (Cav2.1(e47s)), in addition to Cav2.1(e47). We found that the electrophysiological properties of Cav2.1(e47) and Cav2.1(e47s) do not differ from those of Cav2.1, when expressed in $X$. laevis oocytes with Cav $\beta 4 \mathrm{a}, \beta 1 \mathrm{~b}$ or $\beta 2 \mathrm{a}$. Moreover, Cav2.1, Cav2.1(e47) and Cav2.1(e47s) produced C-terminal fragments equivalent to those produced by the human gene. These short and long C-terminal fragments (CT1 and CT1(e47), respectively) interacted with Cav $\beta 4 \mathrm{a}$ in coimmunoprecipitation assays. Co-expression of C-terminal fragments with Cav2.1 or with a truncated Cav2.1 that lacks most of the C-terminus did not affect the channel expression or functional properties. Our study brings new important findings on rat Cav2.1 isoforms and clarifies the role of the $\mathrm{C}$-terminal fragments expressed with the full-length channel in $X$. laevis oocytes. 


\section{MATERIAL AND METHODS}

\subsection{Molecular biology}

The rat brain Cav2.1 (Genbank accession number AAA40806), Cav $\beta 1 b$ (CAA43665), Cav $\beta 2 a$ (AAK14821), Cavß4a (A45982), and Cava281 (AAG28164) cDNAs were cloned in the pMT2 and pcDNA3.1(+) (for Cava281) expression vectors. The fragment encoding Cav2.1 exon 47 was obtained by RT-PCR using specific oligonucleotides and rat cerebellum total RNA (Agilent Technologies). Sequencing of several clones after cloning in the pBS-SK vector (Agilent technologies) revealed the existence of two fragments: TCA50 (full length exon 47) and TCA56 (with a 213nt deletion). They were cloned in frame with rat Cav2.1 in pMT2 using conventional molecular biology techniques to obtain Cav2.1(e47) and Cav2.1(e47s), respectively. Cav2.1, Cav2.1(e47) and Cav2.1(e47s) were also cloned in the pEGFP-N1 expression vector (Clontech) in frame with GFP to obtain Cav2.1-GFP, Cav2.1(e47)-GFP and Cav2.1(e47s)-GFP. The Cterminal fragments CT1, CT1(e47), CT2, and CT2(e47) were PCR amplified, cloned in frame with the RGS-6His tag in a modified pEGFP-N1 vector in which the GFP-encoding sequence was exchanged with the sequence encoding the RGS-6His tag to obtain CT1-6His, CT1(e47)6His, CT2-6His, and CT2(e47)-6His. CT1 and CT1(e47) were also cloned in pEGFP-N1 in frame with GFP to generate CT1-GFP and CT1(e47)-GFP. For the production of Cav2.1 $\Delta \mathrm{CT} 1$ and Cav2.1 $\Delta$ CT2, a stop codon was introduced by PCR after residue K1906 (numbered according to the AAA40806 sequence) or A2043, respectively. The amplified C-terminal fragments were cloned in pBS-SK, fully sequenced, and then, conventional molecular biology techniques were used to put them at the place of the full length Cav2.1 $\mathrm{C}$ terminus. For X. laevis oocyte injections, a cDNA mixture at a molar ratio of 1:1:1 (Cav $\alpha: \operatorname{Cav} \beta: \operatorname{Cav} \alpha 2 \delta)$ was prepared with the addition of water or the cDNA encoding one of the C-terminal fragments tagged with RGS-6His at a molar ratio of 1:1:1:1, unless otherwise indicated.

\subsection{Ethical statement}


This study was carried out in strict accordance with the recommendations and relevant guidelines of our institution. Surgery was performed under anesthesia, and efforts were made to minimize suffering. The care and use of Xenopus conformed to institutional policies and guidelines. The experimental protocols were approved by the "Direction Départementale des Services Vétérinaires" (authorization $\mathrm{N}^{\circ} \mathrm{C} 34.16$ ).

\section{$2.3 X$. laevis oocyte preparation and injection}

Preparation and injection of $X$. laevis oocytes were done as previously described (Cens et al., 1996). After injection of about $15 \mathrm{ng}$ of cDNA, oocytes were maintained at $19^{\circ} \mathrm{C}$ in NDS buffer (96 mM NaCl, $2 \mathrm{mM} \mathrm{KCl}, 1.8 \mathrm{mM} \mathrm{CaCl}, 1 \mathrm{mM} \mathrm{MgCl}$, 5 mM Hepes, $2.5 \mathrm{mM}$ Na-Pyruvate, $0.05 \mathrm{mM}$ gentamycin, $\mathrm{pH} 7.2$ with $\mathrm{NaOH}$ ) renewed daily.

\subsection{Electrophysiology}

Expressed currents were recorded at room temperature using the two-electrode voltage clamp method at day 1-3 after injection, as previously described (Cens et al., 2008). Electrodes were pulled from borosilicate glass and filled with $3 \mathrm{M} \mathrm{KCl}$. Currents were recorded with a Geneclamp 500 amplifier (Molecular Devices), and digitized with a Digidata 1200 converter (Molecular Devices) using the Clampex software (Molecular Devices). The external solution (10mM BaOH, 20mM TEAOH, 2mM CsOH, 50mM N-methyl-D-glucamine, 10mM HEPES, pH 7.2 with methane sulfonic acid) was continuously perfused in the recording chamber at the rate of $1 \mathrm{~mL} / \mathrm{min}$.

Currents were elicited by a two-pulse protocol from a holding potential of $-100 \mathrm{mV}$. The first pulse lasted for $2.5 \mathrm{~s}$ and varied from -80 to $+50 \mathrm{mV}$ in $10 \mathrm{mV}$ increments. The second pulse, separated from the first pulse by a $10 \mathrm{~ms}$ interval at $-100 \mathrm{mV}$, lasted for $400 \mathrm{~ms}$ and was set at $+10 \mathrm{mV}$. The isochronal inactivation curves were obtained by measuring the peak amplitude of the current evoked by the second pulse and by plotting the normalized current values (I/Imax) 
as a function of the voltage reached during the first pulse. They were fitted using the following equation:

$\mathrm{I} / \operatorname{Imax}=\operatorname{Rin}+(1-\operatorname{Rin}) /(1+\exp ((\mathrm{V}-\mathrm{Vi}) / \mathrm{k}))$

where $\mathrm{I}$ is the current amplitude measured during the second pulse following a first depolarization to V, Imax is the current amplitude measured during the second pulse following a first pulse at $-80 \mathrm{mV}, \mathrm{Vi}$ is the half inactivation potential, $\mathrm{k}$ is a slope factor and Rin is the portion of non-inactivating current.

Currents were also elicited by single $400 \mathrm{~ms}$-long depolarizations varying from $-60 \mathrm{mV}$ to +40 $\mathrm{mV}$, from a holding potential of $-100 \mathrm{mV}$. Current-voltage curves were obtained by measuring the peak amplitude and by plotting the normalized current values (I/Imax) as a function of the voltage. They were fitted using the following equation:

$\mathrm{I} / \mathrm{Imax}=\mathrm{G}(\mathrm{V}-\mathrm{Erev}) /(1+\exp ((\mathrm{V}-\mathrm{Va}) / \mathrm{k}))$

where $\mathrm{I}$ is the current amplitude measured during the depolarization to $\mathrm{V}$, Imax is the peak current amplitude measured at the maximum of the current-voltage curve, $G$ is the normalized macroscopic conductance, Erev is the apparent reversal potential, Va is the potential for half activation, and $\mathrm{k}$ is a slope factor. The inactivation velocity (R400) was estimated as the percentage of the peak current that disappeared after $400 \mathrm{~ms}-$ long depolarizations to $+10 \mathrm{mV}$. Recovery from inactivation was determined using a protocol with two pulses at $+10 \mathrm{mV}$ for 5 $\mathrm{s}$ or $100 \mathrm{~ms}$, respectively, from a holding potential of $-100 \mathrm{mV}$, separated by an interval of time between $100 \mathrm{~ms}$ and $8 \mathrm{~s}$. Traces were normalized to the maximum current measured during the first pulse. The percentage of current recovered during the second pulse was plotted as a function of the inter-pulse interval. Traces were fit with a double exponential equation.

2.5 Western blotting and immunoprecipitation assays

Oocytes that expressed Cava1-GFP alone or with 6His-tagged C-terminal fragments were harvested in $10 \mathrm{mM}$ Tris $\mathrm{HCl} \mathrm{pH}$ 7.5, 1 mM PMSF, $1 \mathrm{mM}$ EDTA pH 8, and Complete Protease 
Inhibitor (Roche). Lysates were homogenized with one volume of 2\% Triton X100, $20 \mathrm{mM}$ Tris $\mathrm{pH}$ 7.5, $300 \mathrm{mM} \mathrm{NaCl}, 1 \mathrm{mM}$ EDTA, and incubated on ice for 1 hour. A volume of lysate corresponding to $\sim 2$ oocytes (i.e., an amount sufficient to generate $\sim 4 \mu \mathrm{A}$ total current amplitude measured at $+10 \mathrm{mV}$ ) was separated on Mini-PROTEAN® ${ }^{\mathrm{T}} \mathrm{XX}^{\mathrm{TM}}$ Pre-Cast Gels (BioRad). Immunoblotting was performed with rabbit anti-GFP (1:5000, Sigma-Aldrich Cat\#SAB4301138, RRID: AB_2750576), and mouse anti-RGS6His (1:1000, QIAGEN Cat\#3460, RRID: AB_2687898), and horseradish peroxidase-conjugated goat anti-rabbit (1:5000, Sigma-Aldrich Cat\#A0545, RRID: AB_257896) antibodies or horseradish peroxidaseconjugated goat anti-mouse (1:5000, Sigma-Aldrich Cat\#A9917, RRID: AB_258476). HEK293 cells (RRID: CVCL_0045) were transfected with CT1-GFP or CT1(e47)-GFP alone, or together with Cav $\beta 4$ using Lipofectamine (ThermoFisher). At $24 \mathrm{~h}$ post-transfection, cells were harvested in RIPA Lysis Buffer (Boster) with $1 \mathrm{mM}$ PMSF, $1 \mathrm{mM}$ EDTA pH 8, and Complete Protease Inhibitor. Cell lysates were incubated with a prewashed slurry of $20 \mu 1$ antiGFP-Trap ${ }^{\circledR} \mathrm{A}$ beads (Chromotek) at $4^{\circ} \mathrm{C}$ for $2 \mathrm{~h}$. Immunoprecipitates were recovered in $0.2 \mathrm{M}$ glycine $\mathrm{pH}$ 2.5. Cells lysates and immunoprecipitates were analyzed separately using rabbit anti-GFP (1:5000), mouse anti-Cavß4 (1:1000, abcam Cat\#85788, RRID: AB_1860050), rabbit anti-GAPDH (1:5000, Sigma-Aldrich Cat\#G9545, RRID: AB_796208), and horseradish peroxidase-conjugated goat anti-rabbit (1:5000) or goat anti-mouse (1:5000) antibodies. Detection was performed with the Western Lightning Plus (Perkin Elmer) reagents.

\subsection{Data analysis}

Results were expressed as the mean \pm SEM. The statistical significance of differences between two groups was determined using the non-paired Student's $\underline{t}$ test. 


\section{RESULTS}

3.1 Cloning and functional expression of two long variants of the rat Cav2.1 subunit A cDNA fragment (AAC24516) encoding the entire exon 47 of the rat Cav2.1 calcium channel was previously isolated from pancreas (Ligon et al., 1998), and a partial clone that lacks 123 nucleotides in exon 47 sequence (CAJ09863) was obtained from rat Purkinje neurons (Kanumilli et al., 2006)(Fig. 1). However, to our knowledge, no cDNA encoding the rat Cav2.1 with the long C-terminus is available for functional studies. Therefore, we designed oligonucleotides to amplify rat exon 47 from cerebellum RNA and obtained two different variants. The first one (TCA50, Fig. 1) encoded the entire exon 47 and was identical to the AAC24516 sequence and similar to a clone (AAW56205) isolated from mouse brain (Richards et al., 2007). The second variant (TCA56, Fig. 1) lacked 213 nucleotides compared with TCA50. The deletion in TCA56 was different from the one found in CAJ09863 (Fig. 1) and produced a novel rat Cav2.1 variant. Both deletions were similar to those found in mouse Purkinje neurons (Tsunemi et al., 2002), but due to frameshifts of the open reading frame, the amino acid sequences of the mouse variants differ substantially at the N- (BAB85612) or the C-terminus (BAB85611) of exon 47 (Fig. 1b). We constructed two cDNAs [Cav2.1(e47) and Cav2.1(e47s)] that encode the rat Cav2.1 subunit with full length exon 47 (i.e., TCA50) and the shorter variant (i.e., TCA56), respectively (Fig. 2a). When co-expressed with the Cav $\beta 4 \mathrm{a}$ and Cava281 subunits in X. laevis oocytes (Fig. 2b), Cav2.1, Cav2.1(e47) and Cav2.1(e47s) displayed globally similar electrophysiological properties (Fig. 2c and Table 1). The inactivation kinetics, estimated using the mean R400 values, were also comparable (Fig. 2c and Table 1). We obtained similar results when the three Cav2.1 variants were co-expressed with $\operatorname{Cav} \beta 1 \mathrm{~b}$ or $\operatorname{Cav} \beta 2 \mathrm{a}$ that accelerates or decelerates inactivation, respectively, instead of Cav $\beta 4 \mathrm{a}$ (Table 1). We next investigated the recovery from inactivation that is slower for the human long 
Cav2.1 isoform compared with the short isoform (Adams et al., 2009), but we did not observe this difference when using rat Cav2.1 and Cav2.1(e47) or Cav2.1(e47s) (Fig. 3).

3.2 The rat Cav2.1 transcripts produce C-terminal fragments in X. laevis oocytes

Human long Cav2.1 produces a C-terminal fragment $(\alpha 1 \mathrm{ACT})$ when expressed in HEK or PC12 cells (Kubodera et al., 2003; Kordasiewicz et al., 2006; Ishiguro et al., 2010). However, little is known about the Cav2.1 isoform with the shorter C-terminus and whether C-terminal fragments are produced when the channel is expressed in $X$. laevis oocytes. Therefore, we co-

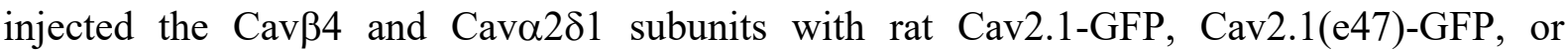
Cav2.1(e47s)-GFP in $X$. laevis oocytes and selected expressing oocytes. Western blot analysis with an anti-GFP antibody (Fig. 4a) showed the presence of full-length Cava1 (band above $250 \mathrm{kDa})$ and of additional bands between $60-90 \mathrm{kDa}$. This demonstrated that rat Cav2.1 produces C-terminal fragments, like human Cav2.1, independently of the presence of exon 47. These C-terminal fragments might influence the expression and electrophysiological properties of Cav2.1 channels. Indeed, it was previously shown that Cav $\beta 4$ interacts specifically with a Cterminus binding domain (SS2) in the rabbit Cav2.1 isoforms BI-1 and BI-2 (Walker et al., 1999; Sandoz et al., 2001). Therefore, we generated two Cav2.1 C-terminal fragments that start at residue I1907 (according to the AAA40806 sequence) and encompass the full-length exon 47 (CT1(e47)) or the C-terminal sequence of the Cav2.1 isoform without exon 47 (CT1) (Fig. 5a). We then expressed C-terminally GFP-tagged CT1 and CT1(e47) together with Cav $\beta 4$ in HEK293 cells. Co-immunoprecipitation assays of protein lysates showed that both CT1 and CT1(e47) interacted with Cav $\beta 4$ (Fig. 4b). These findings indicate that in $X$. laevis oocytes functional Cav2.1 channels coexist with C-terminal fragments, and that these fragments can interact with channel partners, such as $\operatorname{Cav} \beta 4 a$.

3.3 Over-expression of C-terminal fragments do not affect Cav2.1 expression and functional properties in $X$. laevis oocytes 
To evaluate the functional role of the Cav2.1 C-terminus and the potential influence of the different C-terminal fragments, we also generated a rat Cav2.1 subunit that lacks the CT1

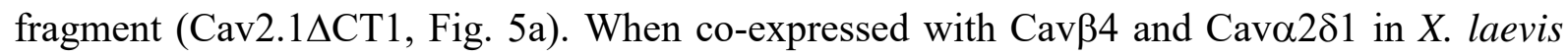
oocytes, Cav2.1 $\Delta \mathrm{CT} 1$ did not produce functional channels (Fig. 5b) even after co-expression of CT1 (not shown). Moreover, co-injection of Cav $\beta 4$ and Cava281 with Cav2.1 and CT1 or CT1(e47) (1:1:1:1 molar ratio) did not, or marginally, affect the parameters of the currentvoltage curves, of the inactivation curves, and the R400 values (Fig. 5c and Table 1). We confirmed the expression of the His-tagged C-terminal fragments in $X$. laevis oocytes by Western blot analysis after the recordings (Fig. 5d). As these fragments interact with the Cav $\beta 4$ subunit (see Fig. 4b), we tested whether they could inhibit Cav2.1 expression when injected in

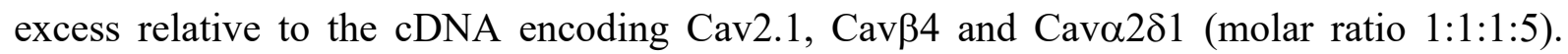
However, the percentage of expressing oocytes was similar when Cav2.1 was expressed alone or with $\mathrm{CT} 1$ or CT1(e47) $(44 \%, 43 \%$, and 36\%, respectively, four independent experiments) (Fig. 5e (left panel)), suggesting that the C-terminal fragments did not inhibit Cav2.1 expression by titrating the Cav $\beta 4$ subunit. We confirmed this lack of effect by systematically measuring the current amplitude in all the expressing oocytes in a single experiment. Indeed, we found similar mean current amplitude values for Cav2.1 expressed alone or with CT1 or CT1(e47) (Fig. 5e (right panel)). Cav2.1 voltage-dependent properties and inactivation kinetics also were not affected after injection in excess of C-terminal fragments (Table 1).

The effect of the co-expressed C-terminal fragments could have been hindered by the presence

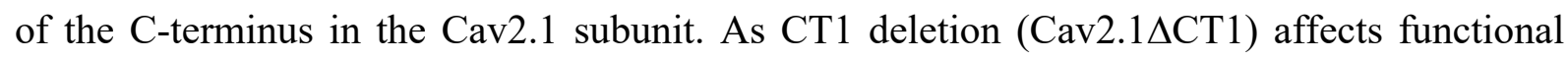
expression, we introduced a stop codon after residue A2043 (according to the AAA40806 sequence) just before the SS2 binding domain (Cav2.1 $\Delta$ CT2, Fig. 6a). When co-expressed with Cav $\beta 4 \mathrm{a}$ and Cav $\alpha 2 \delta 1$ in $X$. laevis oocytes, Cav2.1 $\triangle \mathrm{CT} 2$ gave rise to functional channels (Fig. 6c). Moreover, Cav2.1 $\Delta \mathrm{CT} 2$ electrophysiological properties were undistinguishable from those 
of Cav2.1 (Fig. 6d and Table 1). Co-expression with CT2 or CT2(e47) (Fig. 6a) did not modify Cav2.1 $\triangle$ CT2 properties (Fig. 6d and Table 1). We confirmed CT2 and CT2(e47) expression in the recorded oocytes by Western blotting (Fig. 6b). These results suggest that the lack of effects of the C-terminal fragments observed with full-length Cav2.1 was not due to the presence of the C-terminus in Cav2.1. 


\section{DISCUSSION}

In this study, we cloned Cav2.1(e47) and Cav2.1(e47s), two C-terminal variants of the rat Cav2.1 subunit that harbor the full length (TCA50) or a shorter variant (TCA56) of exon 47 (Fig. 1) respectively, and analyzed their functional properties after expression in $X$. laevis oocytes. Whatever the co-expressed $\operatorname{Cav} \beta$ subunit $(\operatorname{Cav} \beta 1 b, \operatorname{Cav} \beta 2 a$ or $\operatorname{Cav} \beta 4 a)$, the electrophysiological properties of Cav2.1(e47) and Cav2.1(e47s) were comparable to those of the short Cav2.1 isoform. Moreover, these three Cav2.1 isoforms produced C-terminal fragments, like the human CACNA1A gene. These fragments interacted with the Cav $\beta 4$ a subunit in co-immunoprecipitation assays. However, overexpression of these C-terminal fragments with full length Cav2.1 did not modify the expression or the functional properties of the channel.

Exon 47 is present only in some Cav2.1 isoforms because the retention of the GGCAG sequence produces a frameshift of the reading frame (see Fig. 1). Based on our results, we can expect that exon 47 might be expressed in some isoforms of $\alpha 1 \mathrm{ACT}$. Comparison of the different $\mathrm{C}$ terminus variants among species highlights differences in the events leading to their production and also in their sequences. On the other hand, when expressed in HEK293 cells, the three mouse Cav2.1 variants (the short MPc, and the two MPI and MPII variants) show similar electrophysiological properties (Tsunemi et al., 2002). Although the C-terminal sequences of the mouse and rat variants are different, these results are consistent with our observations in $X$. laevis oocytes. The channel activation and inactivation processes are not affected by Cav2.1 variants with different C-terminal sequence (mouse MPI and MPII, and rat Cav2.1(e47) and Cav2.1(e47s)). Similar results were obtained in a study that compared the properties of human Cav2.1 with or without extended C-terminus (fully translated exon 47 with 11 Q residues in the polyQ expansion) co-expressed in HEK293 cells with Cavß4 (Adams et al., 2009) or in another study that used human/mouse chimeric Cav2.1 channels also expressed in HEK293 cells 
(human Cav2.1 sequence with murine exon 47) (Heck et al., 2019). However, the recovery from inactivation was slower and inactivation accumulation was greater for the long than for the short Cav2.1 variant (Adams et al., 2009). Although the rabbit BI-1 and BI-2 variants are quite different (the $\mathrm{C}$ terminus of the long isoform BI-2 harbors an additional Cav $\beta$ binding site besides SS2) (Sandoz et al., 2001), the functional properties of both subunits are very similar when expressed with $\operatorname{Cav} \beta 3$ or $\operatorname{Cav} \beta 4$. Indeed, the additional Cav $\beta$ binding domain in BI-2 seems to affect only the current density (Sandoz et al., 2001). The sequence of the Cav $\beta 4$ SS2 binding domain is well conserved among species, and our results show that rat Cav2.1 Cterminus binds to Cav $\beta 4$, as previously reported for the rabbit Cav2.1 subunit (Walker et al., 1998; Sandoz et al., 2001). However, the results obtained with Cav2.1 $\Delta$ CT2 (without the SS2 binding domain) seem to exclude a functional role for this interaction site when the channel is expressed at the plasma membrane. A similar deletion in a mouse Cav2.1 variant did not affect expression or functional properties when expressed at the calyx of Held in a knock-in mouse model (Lübbert et al., 2017).

In the majority of the central nervous system synapses, P/Q-type calcium channels are the principal $\mathrm{Ca}^{2+}$ channels that trigger the neurotransmitter release. This results from specific interactions between the Cav2.1 subunit and several scaffold proteins that mediate the link between $\mathrm{Ca}^{2+}$ channels, synaptic vesicles, and the exocytosis machinery. Indeed, in Cav2.1, the cytoplasmic loop that links domains II and III contains a synprint interaction domain for the interaction with synaptic proteins, such as syntaxin-1 and synaptotagmin (Rettig et al., 1996; Charvin et al., 1997). This domain is also found in the Cav2.2 subunit that encodes the N-type $\mathrm{Ca}^{2+}$ channel, involved in neurotransmission. Interestingly, a Cav2.2 variant in which the synprint domain is missing has been identified in the human brain (Kaneko et al., 2002). Other sites for the interactions with RIM, MINT1, Rim Binding Proteins and CASK, important for the synaptic localization of the Cav2.1 subunit, are localized in Cav $\alpha$ C-terminus (Maximov et 
al., 1999; Hibino et al., 2002; Kaeser et al., 2011). The relative importance of each of these interactions for Cav2.1 targeting to the presynaptic active zone is a matter of debate (Lübbert et al., 2017), but it is interesting that some of these binding sites are encoded by exon 47, and are therefore not found in all Cav2.1 variants (Hirano et al., 2017). In a recent study, Heck and colleagues found that the different release probability and short-term plasticity of hippocampal synapses that express Cav2.1 with or without exon 47 are due to a difference in surface mobility between these channels (Heck et al., 2019). It is tempting to speculate that Cav2.1 isoforms with different exon 47 variants might specifically modulate these properties.

In conclusion, our results exclude a functional role of the C-terminal fragments on Cav2.1 expression level and electrophysiological properties when expressed in $X$. laevis oocytes. Therefore, we could hypothesize that Cav2.1 C-terminus is mainly involved in Cav2.1 trafficking to specific cellular compartments. Moreover, we found that the C-terminal fragments produced by the Cav2.1 transcripts may contain different splice variants, especially in exon 47 sequence. These fragments, produced thanks to the presence of an IRES, regulate the expression of specific genes (Du et al., 2013). Interestingly, the pathological pQ expansion found in patients with SCA6 abolishes the transcriptional activity of $\alpha 1 \mathrm{ACT}$. Thus, the transcriptional roles of the C-terminal fragments in mouse, rat and rabbit Cav2.1, or of human Cav2.1 without pQ expansion but with a specific C-terminal sequence need to be investigated. 


\title{
ACKNOWLEDGEMENTS
}

The authors wish to acknowledge the Centre National de la Recherche Scientifique, the Institut National de la Santé et de la Recherche Médicale and the Université de Montpellier for their financial support. T.C. wishes to acknowledge Naouel Ougouti for her implication at the beginning of this work.

\section{COMPETING INTERESTS}

The authors declare no competing interest.

\section{AUTHORS' CONTRIBUTIONS}

TC designed the study, performed the molecular biology and the electrophysiological experiments, analyzed the results and wrote most of the paper. TC and CM did the Western blotting and the co-immunoprecipitation experiments. PC, MR and MV provided guidance and support, and critically reviewed the manuscript.

\section{DATA ACCESSIBILITY}

The authors confirm that all data that led to the findings are available and will be shared with the research community upon request to the corresponding author. Please direct all email requests to thierry.cens@inserm.fr.

\author{
ABBREVIATIONS \\ polyQ - tract of glutamine residues \\ IRES - internal ribosome entry site \\ SCA6 - spinocerebellar ataxia type 6 \\ X. laevis - Xenopus laevis
}




\section{REFERENCES}

Adams, P.J., Garcia, E., David, L.S., Mulatz, K.J., Spacey, S.D., \& Snutch, T.P. (2009) $\mathrm{Ca}(\mathrm{V}) 2.1 \mathrm{P} / \mathrm{Q}$-type calcium channel alternative splicing affects the functional impact of familial hemiplegic migraine mutations: implications for calcium channelopathies. Channels, 3, 110-121.

Andrés-Mateos, E., Cruces, J., Renart, J., Solís-Garrido, L.M., Serantes, R., de Lucas-Cerrillo, A.M., \& Montiel, C. (2006) Bovine CACNA1A gene and comparative analysis of the CAG repeats associated to human spinocerebellar ataxia type-6. Gene, 380, 54-61.

Bavassano, C., Eigentler, A., Stanika, R., Obermair, G.J., Boesch, S., Dechant, G., \& Nat, R. (2017) Bicistronic CACNA1A Gene Expression in Neurons Derived from Spinocerebellar Ataxia Type 6 Patient-Induced Pluripotent Stem Cells. Stem Cells Dev., 26, $1612-1625$.

Buraei, Z. \& Yang, J. (2010) The $ß$ subunit of voltage-gated Ca2+ channels. Physiol. Rev., 90, $1461-1506$.

Cens, T., Leyris, J.-P., \& Charnet, P. (2008) Introduction into Ca(v)2.1 of the homologous mutation of $\mathrm{Ca}(\mathrm{v}) 1.2$ causing the Timothy syndrome questions the role of V421 in the phenotypic definition of P-type Ca(2+) channel. Pflugers Arch., 457, 417-430.

Cens, T., Mangoni, M.E., Nargeot, J., \& Charnet, P. (1996) Modulation of the a1A Ca2+ channel by $\beta$ subunits at physiological Ca2+ concentration. FEBS Lett., 391, 232-237.

Charvin, N., Lévêque, C., Walker, D., Berton, F., Raymond, C., Kataoka, M., Shoji-Kasai, Y., Takahashi, M., De Waard, M., \& Seagar, M.J. (1997) Direct interaction of the calcium sensor protein synaptotagmin I with a cytoplasmic domain of the alpha 1A subunit of the P/Q-type calcium channel. EMBO J., 16, 4591-4596.

Du, X., Wang, J., Zhu, H., Rinaldo, L., Lamar, K.-M., Palmenberg, A.C., Hansel, C., \& Gomez, C.M. (2013) Second cistron in CACNA1A gene encodes a transcription factor 
mediating cerebellar development and SCA6. Cell, 154, 118-133.

Geib, S., Sandoz, G., Cornet, V., Mabrouk, K., Fund-Saunier, O., Bichet, D., Villaz, M., Hoshi, T., Sabatier, J.-M., \& De Waard, M. (2002) The interaction between the I-II loop and the III-IV loop of Cav2.1 contributes to voltage-dependent inactivation in a beta dependent manner. J. Biol. Chem., 277, 10003-10013.

Hans, M., Urrutia, A., Deal, C., Brust, P.F., Stauderman, K., Ellis, S.B., Harpold, M.M., Johnson, E.C., \& Williams, M.E. (1999) Structural elements in domain IV that influence biophysical and pharmacological properties of human alpha1 A-containing high-voltageactivated calcium channels. Biophys. J., 76, 1384-1400.

Heck, J., Parutto, P., Ciuraszkiewicz, A., Bikbaev, A., Freund, R., Mitlöhner, J., AndresAlonso, M., Fejtova, A., Holcman, D., \& Heine, M. (2019) Transient Confinement of CaV2.1 Ca2+-Channel Splice Variants Shapes Synaptic Short-Term Plasticity. Neuron, 103, 66-79.e12.

Hibino, H., Pironkova, R., Onwumere, O., Vologodskaia, M., Hudspeth, A.J., \& Lesage, F. (2002) RIM binding proteins (RBPs) couple Rab3-interacting molecules (RIMs) to voltage-gated $\mathrm{Ca}(2+)$ channels. Neuron, 34, 411-423.

Hirano, M., Takada, Y., Wong, C.F., Yamaguchi, K., Kotani, H., Kurokawa, T., Mori, M.X., Snutch, T.P., Ronjat, M., De Waard, M., \& Mori, Y. (2017) C-terminal splice variants of P/Q-type Ca2+ channel CaV2.1 $\alpha 1$ subunits are differentially regulated by Rab3interacting molecule proteins. J. Biol. Chem., 292, 9365-9381.

Ishida, Y., Kawakami, H., Kitajima, H., Nishiyama, A., Sasai, Y., Inoue, H., \& Muguruma, K. (2016) Vulnerability of Purkinje Cells Generated from Spinocerebellar Ataxia Type 6 Patient-Derived iPSCs. Cell Rep., 17, 1482-1490.

Ishiguro, T., Ishikawa, K., Takahashi, M., Obayashi, M., Amino, T., Sato, N., Sakamoto, M., Fujigasaki, H., Tsuruta, F., Dolmetsch, R., Arai, T., Sasaki, H., Nagashima, K., Kato, T., 
Yamada, M., Takahashi, H., Hashizume, Y., \& Mizusawa, H. (2010) The carboxyterminal fragment of alpha(1A) calcium channel preferentially aggregates in the cytoplasm of human spinocerebellar ataxia type 6 Purkinje cells. Acta Neuropathol., 119, 447-464.

Jun, K., Piedras-Rentería, E.S., Smith, S.M., Wheeler, D.B., Lee, S.B., Lee, T.G., Chin, H., Adams, M.E., Scheller, R.H., Tsien, R.W., \& Shin, H.S. (1999) Ablation of P/Q-type $\mathrm{Ca}(2+)$ channel currents, altered synaptic transmission, and progressive ataxia in mice lacking the alpha(1A)-subunit. Proc. Natl. Acad. Sci. U. S. A., 96, 15245-15250.

Kaeser, P.S., Deng, L., Wang, Y., Dulubova, I., Liu, X., Rizo, J., \& Südhof, T.C. (2011) RIM proteins tether $\mathrm{Ca} 2+$ channels to presynaptic active zones via a direct PDZ-domain interaction. Cell, 144, 282-295.

Kaneko, S., Cooper, C.B., Nishioka, N., Yamasaki, H., Suzuki, A., Jarvis, S.E., Akaike, A., Satoh, M., \& Zamponi, G.W. (2002) Identification and characterization of novel human $\mathrm{Ca}(\mathrm{v}) 2.2$ (alpha 1B) calcium channel variants lacking the synaptic protein interaction site. J. Neurosci., 22, 82-92.

Kanumilli, S., Tringham, E.W., Payne, C.E., Dupere, J.R.B., Venkateswarlu, K., \& Usowicz, M.M. (2006) Alternative splicing generates a smaller assortment of CaV2.1 transcripts in cerebellar Purkinje cells than in the cerebellum. Physiol. Genomics, 24, 86-96.

Kordasiewicz, H.B., Thompson, R.M., Clark, H.B., \& Gomez, C.M. (2006) C-termini of P/Qtype $\mathrm{Ca} 2+$ channel alpha1 A subunits translocate to nuclei and promote polyglutaminemediated toxicity. Hum. Mol. Genet., 15, 1587-1599.

Kubodera, T., Yokota, T., Ohwada, K., Ishikawa, K., Miura, H., Matsuoka, T., \& Mizusawa, H. (2003) Proteolytic cleavage and cellular toxicity of the human alpha1A calcium channel in spinocerebellar ataxia type 6. Neurosci. Lett., 341, 74-78.

Ligon, B., Boyd, A.E., \& Dunlap, K. (1998) Class A calcium channel variants in pancreatic 
islets and their role in insulin secretion. J. Biol. Chem., 273, 13905-13911.

Lübbert, M., Goral, R.O., Satterfield, R., Putzke, T., van den Maagdenberg, A.M., Kamasawa, N., \& Young, S.M. (2017) A novel region in the CaV2.1 $\alpha 1$ subunit C-terminus regulates fast synaptic vesicle fusion and vesicle docking at the mammalian presynaptic active zone. Elife, 6, e28412.

Matsuyama, Z., Wakamori, M., Mori, Y., Kawakami, H., Nakamura, S., \& Imoto, K. (1999) Direct alteration of the P/Q-type $\mathrm{Ca} 2+$ channel property by polyglutamine expansion in spinocerebellar ataxia 6. J. Neurosci., 19, RC14.

Maximov, A., Südhof, T.C., \& Bezprozvanny, I. (1999) Association of neuronal calcium channels with modular adaptor proteins. J. Biol. Chem., 274, 24453-24456.

McDonough, S.I., Swartz, K.J., Mintz, I.M., Boland, L.M., \& Bean, B.P. (1996) Inhibition of calcium channels in rat central and peripheral neurons by omega-conotoxin MVIIC. $J$. Neurosci., 16, 2612-2623.

Mintz, I.M., Adams, M.E., \& Bean, B.P. (1992) P-type calcium channels in rat central and peripheral neurons. Neuron, 9, 85-95.

Mori, Y., Friedrich, T., Kim, M.-S., Mikami, A., Nakai, J., Ruth, P., Bosse, E., Hofmann, F., Flockerzi, V., Furuichi, T., Mikoshiba, K., Imoto, K., Tanabe, T., \& Numa, S. (1991) Primary structure and functional expression from complementary DNA of a brain calcium channel. Nature, 350, 398-402.

Piedras-Renteria, E.S., Watase, K., Harata, N., Zhuchenko, O., Zoghbi, H.Y., Lee, C.C., \& Tsien, R.W. (2001) Increased expression of alpha 1A Ca2+ channel currents arising from expanded trinucleotide repeats in spinocerebellar ataxia type 6. J. Neurosci., 21, 91859193.

Pinto, A., Gillard, S., Moss, F., Whyte, K., Brust, P., Williams, M., Stauderman, K., Harpold, M., Lang, B., Newsom-Davis, J., Bleakman, D., Lodge, D., \& Boot, J. (1998) Human 
autoantibodies specific for the 1A calcium channel subunit reduce both P-type and Qtype calcium currents in cerebellar neurons. Proc. Natl. Acad. Sci., 95, 8328-8333.

Restituito, S., Thompson, R.M., Eliet, J., Raike, R.S., Riedl, M., Charnet, P., \& Gomez, C.M. (2000) The polyglutamine expansion in spinocerebellar ataxia type 6 causes a beta subunit-specific enhanced activation of P/Q-type calcium channels in Xenopus oocytes. J. Neurosci., 20, 6394-6403.

Rettig, J., Sheng, Z.H., Kim, D.K., Hodson, C.D., Snutch, T.P., \& Catterall, W.A. (1996) Isoform-specific interaction of the alpha1A subunits of brain $\mathrm{Ca} 2+$ channels with the presynaptic proteins syntaxin and SNAP-25. Proc. Natl. Acad. Sci. U. S. A., 93, $7363-$ 7368.

Richards, K.S., Swensen, A.M., Lipscombe, D., \& Bommert, K. (2007) Novel CaV2.1 clone replicates many properties of Purkinje cell CaV2.1 current. Eur. J. Neurosci., 26, 29502961.

Saegusa, H., Wakamori, M., Matsuda, Y., Wang, J., Mori, Y., Zong, S., \& Tanabe, T. (2007) Properties of human Cav2.1 channel with a spinocerebellar ataxia type 6 mutation expressed in Purkinje cells. Mol. Cell. Neurosci., 34, 261-270.

Sandoz, G., Bichet, D., Cornet, V., Mori, Y., Felix, R., \& De Waard, M. (2001) Distinct properties and differential beta subunit regulation of two C-terminal isoforms of the $\mathrm{P} / \mathrm{Q}-$ type $\mathrm{Ca}(2+)$-channel alpha(1A) subunit. Eur. J. Neurosci., 14, 987-997.

Soong, T.W., DeMaria, C.D., Alvania, R.S., Zweifel, L.S., Liang, M.C., Mittman, S., Agnew, W.S., \& Yue, D.T. (2002) Systematic identification of splice variants in human P/Q-type channel alpha1(2.1) subunits: implications for current density and Ca2+-dependent inactivation. J. Neurosci., 22, 10142-10152.

Toru, S., Murakoshi, T., Ishikawa, K., Saegusa, H., Fujigasaki, H., Uchihara, T., Nagayama, S., Osanai, M., Mizusawa, H., \& Tanabe, T. (2000) Spinocerebellar ataxia type 6 
mutation alters P-type calcium channel function. J. Biol. Chem., 275, 10893-10898.

Tsunemi, T., Saegusa, H., Ishikawa, K., Nagayama, S., Murakoshi, T., Mizusawa, H., \& Tanabe, T. (2002) Novel Cav2.1 splice variants isolated from Purkinje cells do not generate P-type Ca2+ current. J. Biol. Chem., 277, 7214-7221.

Veneziano, L., Guida, S., Mantuano, E., Bernard, P., Tarantino, P., Boccone, L., Hisama, F.M., Carrera, P., Jodice, C., \& Frontali, M. (2009) Newly characterised 5' and 3' regions of CACNA1A gene harbour mutations associated with Familial Hemiplegic Migraine and Episodic Ataxia. J. Neurol. Sci., 276, 31-37.

Walker, D., Bichet, D., Campbell, K.P., \& De Waard, M. (1998) A beta 4 isoform-specific interaction site in the carboxyl-terminal region of the voltage-dependent $\mathrm{Ca} 2+$ channel alpha 1A subunit. J. Biol. Chem., 273, 2361-2367.

Walker, D., Bichet, D., Geib, S., Mori, E., Cornet, V., Snutch, T.P., Mori, Y., \& De Waard, M. (1999) A new beta subtype-specific interaction in alpha1A subunit controls P/Q-type Ca2+ channel activation. J. Biol. Chem., 274, 12383-12390.

Zhuchenko, O., Bailey, J., Bonnen, P., Ashizawa, T., Stockton, D.W., Amos, C., Dobyns, W.B., Subramony, S.H., Zoghbi, H.Y., \& Lee, C.C. (1997) Autosomal dominant cerebellar ataxia (SCA6) associated with small polyglutamine expansions in the $\alpha 1 \mathrm{~A}-$ voltage-dependent calcium channel. Nat. Genet., 15, 62-69. 
Table 1: Parameters of the voltage-current curves and of the inactivation curves, and R400 values for all the subunit combinations (Cav $\alpha 2 \delta 1$ was always present). Data are the mean \pm S.E.M. of $n$ oocytes. Statistical significance ( $p$ values using Student's $t$ test) vs Cav2.1 $\beta 4, p ; v s$ Cav2.1 $\beta 1 b$, ${ }^{*} p$; vs Cav2.1ß2a, ${ }^{* *} p$; vs Cav2.1 $\Delta \mathrm{C} 2 \beta 4,{ }^{* * *} p$, is given for all parameters.

\begin{tabular}{|c|c|c|c|c|c|c|c|c|c|c|}
\hline & \multicolumn{4}{|c|}{ Current voltage curves } & \multicolumn{4}{|c|}{ Inactivation curves } & & \\
\hline & $\begin{array}{c}\mathrm{Va} \\
(\mathrm{mV})\end{array}$ & $\begin{array}{c}\mathrm{ka} \\
(\mathrm{mV})\end{array}$ & $\begin{array}{l}\text { Erev } \\
(\mathrm{mV})\end{array}$ & $\mathrm{n}$ & $\begin{array}{c}\mathrm{Vi} \\
(\mathrm{mV})\end{array}$ & $\begin{array}{c}\text { ki } \\
(\mathrm{mV})\end{array}$ & $\mathrm{R}$ & $\mathrm{n}$ & $\mathrm{R} 400$ & $\mathrm{n}$ \\
\hline Cav2.1ß4 & $-9.0 \pm 1.0$ & $-3.2 \pm 0.3$ & $54 \pm 1$ & 31 & $-22.9 \pm 0.7$ & $7.1 \pm 0.2$ & $0.14 \pm 0.01$ & 26 & $0.43 \pm 0.02$ & 33 \\
\hline Cav2.1ß4CT1 & $\begin{array}{c}-8.2 \pm 1.2 \\
p=0.62\end{array}$ & $\begin{array}{l}-4.5 \pm 0.2 \\
p=0.0005\end{array}$ & $\begin{array}{c}51 \pm 1 \\
p=0.0146\end{array}$ & 24 & $\begin{array}{l}-26.0 \pm 0.9 \\
p=0.0094\end{array}$ & $\begin{array}{c}8.0 \pm 0.3 \\
p=0.0402\end{array}$ & $\begin{array}{c}0.15 \pm 0.02 \\
p=0.71\end{array}$ & 14 & $\begin{array}{c}0.45 \pm 0.03 \\
p=0.35\end{array}$ & 22 \\
\hline Cav2.1ß4CT1 (1:5) & $\begin{array}{l}-11.9 \pm 1.4 \\
p=0.1056\end{array}$ & $\begin{array}{c}-3.2 \pm 0.4 \\
p=0.99\end{array}$ & $\begin{array}{c}50 \pm 1 \\
p=0.60\end{array}$ & 11 & $\begin{array}{l}-28.2 \pm 0.6 \\
p=0.0003\end{array}$ & $\begin{array}{l}6.7 \pm 0.2 \\
p=0.37\end{array}$ & $\begin{array}{c}0.12 \pm 0.02 \\
p=0.62\end{array}$ & 7 & $\begin{array}{l}0.49 \pm 0.04 \\
p=0.1185\end{array}$ & 12 \\
\hline Cav2.1ß4CT1(e47) & $\begin{array}{c}-8.6 \pm 1.3 \\
p=0.65\end{array}$ & $\begin{array}{l}-4.1 \pm 0.3 \\
p=0.0077\end{array}$ & $\begin{array}{c}53 \pm 1 \\
p=0.37\end{array}$ & 28 & $\begin{array}{l}-27.4 \pm 1.0 \\
p=0.0003\end{array}$ & $\begin{array}{c}8.6 \pm 0.3 \\
p=0.0004\end{array}$ & $\begin{array}{l}0.09 \pm 0.02 \\
p=0.0376\end{array}$ & 21 & $\begin{array}{c}0.40 \pm 0.03 \\
p=0.55\end{array}$ & 34 \\
\hline
\end{tabular}




\begin{tabular}{|c|c|c|c|c|c|c|c|c|c|c|}
\hline $\begin{array}{c}\text { Cav2.1 } \beta 4 \mathrm{CT} 1(\mathrm{e} 47) \\
(1: 5)\end{array}$ & $\begin{array}{l}-12.2 \pm 1.9 \\
p=0.2257\end{array}$ & $\begin{array}{c}-3.0 \pm 0.4 \\
p=0.81\end{array}$ & $\begin{array}{c}50 \pm 1 \\
p=0.1271\end{array}$ & 4 & $\begin{array}{l}-25.4 \pm 0.4 \\
p=0.1470\end{array}$ & $\begin{array}{l}6.7 \pm 0.8 \\
p=0.57\end{array}$ & $\begin{array}{l}0.08 \pm 0.01 \\
p=0.1306\end{array}$ & 4 & $\begin{array}{c}0.48 \pm 0.04 \\
p=0.34\end{array}$ & 4 \\
\hline Cav2.1 $\beta 4 \mathrm{CT} 2$ & $\begin{array}{l}-6.6 \pm 1.3 \\
p=0.1456\end{array}$ & $\begin{array}{l}-4.2 \pm 0.4 \\
p=0.0341\end{array}$ & $\begin{array}{c}52 \pm 2 \\
p=0.2552\end{array}$ & 24 & $\begin{array}{c}-23.4 \pm 1.0 \\
p=0.69\end{array}$ & $\begin{array}{l}7.3 \pm 0.2 \\
p=0.65\end{array}$ & $\begin{array}{c}0.13 \pm 0.02 \\
p=0.65\end{array}$ & 18 & $\begin{array}{c}0.39 \pm 0.03 \\
p=0.42\end{array}$ & 24 \\
\hline Cav2.1ß4CT2(e47) & $\begin{array}{c}-9.2 \pm 1.1 \\
p=0.88\end{array}$ & $\begin{array}{c}-3.3 \pm 0.4 \\
p=0.84\end{array}$ & $\begin{array}{c}55 \pm 1 \\
p=0.40\end{array}$ & 20 & $\begin{array}{l}-25.7 \pm 1.1 \\
p=0.0258\end{array}$ & $\begin{array}{c}8.1 \pm 0.3 \\
p=0.0188\end{array}$ & $\begin{array}{l}0.11 \pm 0.01 \\
p=0.1011\end{array}$ & 18 & $\begin{array}{c}0.41 \pm 0.03 \\
p=0.82\end{array}$ & 20 \\
\hline Cav2.1(e47)ß4 & $\begin{array}{l}-6.9 \pm 1.0 \\
p=0.1248\end{array}$ & $\begin{array}{l}-3.8 \pm 0.2 \\
p=0.1245\end{array}$ & $\begin{array}{c}52 \pm 1 \\
p=0.30\end{array}$ & 37 & $\begin{array}{c}-23.4 \pm 1.0 \\
p=0.72\end{array}$ & $\begin{array}{c}8.2 \pm 0.2 \\
p=0.0021\end{array}$ & $\begin{array}{l}0.08 \pm 0.01 \\
p=0.0003\end{array}$ & 35 & $\begin{array}{c}0.39 \pm 0.03 \\
p=0.35\end{array}$ & 21 \\
\hline Cav2.1(e47s) $\beta 4$ & $\begin{array}{c}-7.1 \pm 1.1 \\
p=0.24\end{array}$ & $\begin{array}{l}-4.8 \pm 0.3 \\
p=0.0014\end{array}$ & $\begin{array}{c}52 \pm 1 \\
p=0.1641\end{array}$ & 13 & $\begin{array}{l}-19.1 \pm 1.5 \\
p=0.0122\end{array}$ & $\begin{array}{l}7.1 \pm 0.3 \\
p=0.95\end{array}$ & $\begin{array}{c}0.14 \pm 0.02 \\
p=0.99\end{array}$ & 14 & $\begin{array}{c}0.43 \pm 0.03 \\
p=0.73\end{array}$ & 15 \\
\hline Cav2.1 $\beta 1 \mathrm{~b}$ & $-8.2 \pm 0.7$ & $-3.7 \pm 0.2$ & $52 \pm 1$ & 9 & $-29.8 \pm 0.7$ & $6.8 \pm 0.3$ & $0.09 \pm 0.01$ & 9 & $0.33 \pm 0.03$ & 9 \\
\hline Cav2.1(e47) $\beta 1 \mathrm{~b}$ & $\begin{array}{l}-11.2 \pm 1.3 \\
{ }^{*} p=0.0544\end{array}$ & $\begin{array}{l}-3.4 \pm 0.4 \\
{ }^{*} p=0.42\end{array}$ & $\begin{array}{c}52 \pm 1 \\
* p=0.99\end{array}$ & 8 & $\begin{array}{l}-32.3 \pm 1.5 \\
* p=0.1547\end{array}$ & $\begin{array}{c}7.3 \pm 0.2 \\
* p=0.1709\end{array}$ & $\begin{array}{l}0.07 \pm 0.01 \\
* p=0.1130\end{array}$ & 9 & $\begin{array}{c}0.33 \pm 0.01 \\
* p=0.94\end{array}$ & 9 \\
\hline
\end{tabular}




\begin{tabular}{|c|c|c|c|c|c|c|c|c|c|c|}
\hline Cav2.1(e47s) $\beta 1 \mathrm{~b}$ & $\begin{array}{l}-11.4 \pm 1.8 \\
* p=0.0894\end{array}$ & $\begin{array}{c}-3.2 \pm 0.2 \\
* p=0.1159\end{array}$ & $\begin{array}{c}51 \pm 1 \\
* p=0.2627\end{array}$ & 7 & $\begin{array}{c}-32.0 \pm 1.9 \\
* p=0.34\end{array}$ & $\begin{array}{l}6.9 \pm 0.2 \\
* p=0.78\end{array}$ & $\begin{array}{l}0.1 \pm 0.01 \\
* p=0.50\end{array}$ & 11 & $\begin{array}{c}0.34 \pm 0.02 \\
* p=0.77\end{array}$ & 11 \\
\hline Cav2.1ß2a & $-3.4 \pm 0.7$ & $-4.1 \pm 0.2$ & $54 \pm 1$ & 21 & $-11.2 \pm 0.7$ & $6.8 \pm 0.7$ & $0.38 \pm 0.03$ & 17 & $0.69 \pm 0.04$ & 21 \\
\hline Cav2.1(e47) $\beta 2 \mathrm{a}$ & $\begin{array}{l}-3.6 \pm 1.3 \\
* * p=0.89\end{array}$ & $\begin{array}{l}-4.3 \pm 0.3 \\
* * p=0.66\end{array}$ & $\begin{array}{c}54 \pm 1 \\
* * p=0.83\end{array}$ & 13 & $\begin{array}{l}-11.0 \pm 1.5 \\
* * p=0.91\end{array}$ & $\begin{array}{c}6.1 \pm 0.6 \\
* * p=0.44\end{array}$ & $\begin{array}{l}0.36 \pm 0.10 \\
* * p=0.75\end{array}$ & 8 & $\begin{array}{l}0.70 \pm 0.08 \\
* * p=0.89\end{array}$ & 9 \\
\hline $\operatorname{Cav} 2.1(\mathrm{e} 47 \mathrm{~s}) \beta 2 \mathrm{a}$ & $\begin{array}{l}-3.2 \pm 1.4 \\
* * p=0.87\end{array}$ & $\begin{array}{l}-4.3 \pm 0.4 \\
* * p=0.67\end{array}$ & $\begin{array}{c}54 \pm 1 \\
* * p=0.70\end{array}$ & 10 & $\begin{array}{c}-12.9 \pm 1.0 \\
* * p=0.1781\end{array}$ & $\begin{array}{c}5.7 \pm 0.5 \\
* * p=0.2040\end{array}$ & $\begin{array}{l}0.33 \pm 0.06 \\
* * p=0.38\end{array}$ & 11 & $\begin{array}{l}0.64 \pm 0.05 \\
* * p=0.43\end{array}$ & 12 \\
\hline $\operatorname{Cav} 2.1 \Delta \mathrm{C} 2 \beta 4$ & $\begin{array}{l}-9.9 \pm 0.9 \\
p=0.50\end{array}$ & $\begin{array}{c}-3.4 \pm 0.2 \\
p=0.73\end{array}$ & $\begin{array}{c}53 \pm 1 \\
p=0.31\end{array}$ & 16 & $\begin{array}{l}-25.7 \pm 0.6 \\
p=0.0054\end{array}$ & $\begin{array}{l}7.0 \pm 0.3 \\
p=0.88\end{array}$ & $\begin{array}{c}0.13 \pm 0.02 \\
p=0.76\end{array}$ & 18 & $\begin{array}{c}0.45 \pm 0.03 \\
p=0.30\end{array}$ & 17 \\
\hline Cav2.1 $\Delta \mathrm{C} 2 \beta 4 \mathrm{CT} 2$ & $\begin{array}{c}-7.0 \pm 1.1 \\
* * * p=0.0473\end{array}$ & $\begin{array}{c}-3.7 \pm 0.3 \\
* * * p=0.41\end{array}$ & $\begin{array}{c}53 \pm 1 \\
* * * p=0.88\end{array}$ & 19 & $\begin{array}{c}-22.8 \pm 0.9 \\
* * * p=0.0120\end{array}$ & $\begin{array}{c}7.8 \pm 0.3 \\
* * * p=0.0640\end{array}$ & $\begin{array}{c}0.10 \pm 0.02 \\
* * * p=0.0918\end{array}$ & 18 & $\begin{array}{c}0.38 \pm 0.03 \\
* * * p=0.065\end{array}$ & 19 \\
\hline Cav2.1 $1 \Delta \mathrm{C} 2 \beta 4 \mathrm{CT} 2(\mathrm{e} 47)$ & $\begin{array}{c}-7.1 \pm 1.2 \\
* * * p=0.0663\end{array}$ & $\begin{array}{c}-4.4 \pm 0.6 \\
* * * p=0.0860\end{array}$ & $\begin{array}{c}52 \pm 2 \\
* * * p=0.48\end{array}$ & 14 & $\begin{array}{c}-24.0 \pm 1.5 \\
* * * p=0.29\end{array}$ & $\begin{array}{c}9.8 \pm 0.9 \\
* * * p=0.0033\end{array}$ & $\begin{array}{l}0.12 \pm 0.03 \\
* * * p=0.63\end{array}$ & 15 & $\begin{array}{l}0.45 \pm 0.04 \\
* * * p=0.98\end{array}$ & 14 \\
\hline
\end{tabular}





\section{FIGURE CAPTIONS}

Figure 1. Summary of the events leading to the expression of Cav2.1 isoforms with different C-terminus sequences in the rat and mouse. (a) The use of an alternative acceptor site at the exon 46-47 boundary allows the insertion of the GGCAG sequence at the beginning of exon 47 and the in-frame translation of exon 47 , leading to Cav2.1 isoforms with full-length or deleted exon 47 in the rat (AAC24516, TCA50, CAJ09863, TCA56) and mouse (AAW56205, BAB85612, BAB85611). Conversely, omission of the GGCAG sequence causes a frameshift, leading to a stop codon at the beginning of exon 47 (AAC52940, AAC40806) (b) Alignment of the amino acid sequences of the extended C-terminus of rat and mouse Cav2.1.

Figure 2. The short and the two long rat Cav2.1 variants show similar functional properties. (a) Schematic representation of the three rat Cav2.1, Cav2.1(e47) and Cav2.1(e47s) variants that differ at the C-terminus. The arrow indicates where the translation of human $\alpha 1 \mathrm{ACT}$ begins (M1911). (b) Representative current traces recorded from X. laevis oocytes that express the indicated Cav $\alpha$ subunit together with $\operatorname{Cav} \beta 4 \mathrm{a}$ and Cav $\alpha 2 \delta 1$. Currents were elicited by $400 \mathrm{~ms}-$ long step depolarizations from a holding potential of $-100 \mathrm{mV}$ to potentials between $-60 \mathrm{mV}$ and $+40 \mathrm{mV}$. Scale bars, $500 \mathrm{nA}$. (c) Current voltage curves (left), isochronal inactivation curves (middle), and R400 values (right) obtained for Cav2.1, Cav2.1(e47) and Cav2.1(e47s) in X. laevis oocytes that express the indicated Cav $\alpha$ subunit together with Cav $\beta 4 a$ and Cava281. The parameters of both curves and the R400values are similar or marginally affected (see Table 1). n.s = non-significant.

Figure 3. The rat Cav2.1, Cav2.1(e47) and Cav2.1(e47s) variants exhibit similar recovery from inactivation. (a) Representative current traces obtained in $X$. laevis oocytes that co-express the indicated Cav2.1 variants with $\operatorname{Cav} \beta 4 \mathrm{a}$ and $\operatorname{Cav} \alpha 2 \delta 1$. The experimental protocol is described 
above the traces. Depolarization to $+10 \mathrm{mV}$ for $5 \mathrm{~s}$ precedes a second 100ms-long depolarization to $+10 \mathrm{mV}$ after inter-pulse intervals between $100 \mathrm{~ms}$ and $8 \mathrm{~s}$. Scale bar, $500 \mathrm{nA}$. (b) Percentage of current recovery plotted against the inter-pulse duration for the three variants. (c) The percentage of current recovery after $8 \mathrm{~s}$ of Cav2.1 is significantly smaller than that of Cav2.1(e47) $(86 \pm 1 \%, \mathrm{n}=9$ and $89 \pm 1 \%, \mathrm{n}=10$, respectively; $p=0.0036)$ and is similar to that of Cav2.1(e47s) $(85 \pm 1 \%, \mathrm{n}=6 ; p=0.49) . \mathrm{n} . \mathrm{s}=$ non-significant.

Figure 4. Rat Cav2.1 variants produce C-terminal fragments that interact with Cav $\beta 4 a$. (a) Western blot (WB) analysis of lysates from $X$. laevis oocytes that express Cav2.1, Cav2.1(e47) or Cav2.1(e47s) together with Cav $\beta 4$ and Cav $\alpha 2 \delta 1$. The Cav $\alpha$ subunits were detected with an anti-GFP antibody (top), while Cav $\beta 4$ a was detected with a specific anti-Cav $\beta 4$ antibody (bottom). The expected molecular masses were 58, 278, 294 and $287 \mathrm{kDa}$ for Cav $\beta 4 \mathrm{a}$, Cav2.1GFP, Cav2.1(e47)-GFP and Cav2.1(e47s)-GFP, respectively. The three variants produce Cterminal fragments with an apparent molecular mass between 60 and $100 \mathrm{kDa}$, depending on the size of the Cav $\alpha$ C-terminus. Doublets (asterisks) are due to GFP (see also Fig. 4b) and disappear when using the 6His tag (see Fig. 5d). NI, lysate obtained from non-injected oocytes. (b) Co-immunoprecipitation assays using protein lysates from HEK293 cells transfected with CT1-GFP or CT1(e47)-GFP alone or with Cav $\beta 4$ a show the physical interaction of the Cav $\beta 4$ with both C-terminal fragments. The expected molecular masses were 64 and $80 \mathrm{kDa}$ for CT1GFP and CT1(e47)-GFP, respectively.

Figure 5. Over-expression of C-terminal fragments does not affect Cav2.1 expression and functional properties. (a) Schematic representation of the deleted Cav2.1 (Cav2.1 $\Delta \mathrm{CT} 1$ ), and the short (CT1) and the long (CT1(e47)) C-terminal fragments. (b) Representative current traces recorded from $X$. laevis oocytes injected with the indicated Cav $\alpha$ subunit, Cav $\beta 4 a$ and 
Cava281, alone or with the short or the long C-terminal fragment tagged with $6 \mathrm{His}$ at the Cterminus (1:1:1:1 molar ratio). Currents were elicited by 400ms-long step depolarizations from a holding potential of $-100 \mathrm{mV}$ to potentials between $-60 \mathrm{mV}$ and $+40 \mathrm{mV}$. Scale bars, $500 \mathrm{nA}$. (c) Current voltage curves (left), isochronal inactivation curves (middle), and R400 values (right) obtained for Cav2.1 alone, or with the short or the long C-terminal fragment. The parameters of both curves and the R400 values are similar or marginally affected (see Table 1). (d) Western blot analysis of lysates from $X$. laevis oocytes injected with Cav2.1 alone $\left(\mathrm{H}_{2} \mathrm{O}\right)$, or with CT1-6His or CT1(e47)-6His and collected after recordings. The expected molecular masses were 38 and $54 \mathrm{kDa}$ for CT1-6His and CT1(e47)-6His, respectively. NI, lysate obtained from non-injected oocytes. (e) Percentage of expressing oocytes in four independent experiments (right) and mean amplitude of the currents recorded from all the expressing oocytes in one of these four experiments (left). Oocytes were injected with Cav2.1, Cav $\beta 4 \mathrm{a}$ and Cava281 alone, or with the short or the long C-terminal fragment (1:1:1:5 molar ratio), and recording performed two days later. The mean amplitude currents measured for Cav2.1 alone $(1255 \pm 176 \mathrm{nA}, \mathrm{n}=19)$, with CT1 $(1249 \pm 122 \mathrm{nA}, \mathrm{n}=11)$ or with CT1(e47) $(1263 \pm 177 \mathrm{nA}$, $\mathrm{n}=18)$ were similar $(p=0.98$ and $p=0.99$, respectively $) . \mathrm{n} . \mathrm{s}=$ non-significant.

Figure 6. Deletion of the $\operatorname{Cav} \beta$ binding domain in Cav2.1 C-terminus does not affect Cav2.1 functional properties. (a) Schematic representation of Cav2.1 $\Delta \mathrm{CT} 2$ and the C-terminal fragments CT2 and CT2(e47). (b) Western blot analysis of lysates from X. laevis oocytes expressing Cav2.1 alone $\left(\mathrm{H}_{2} \mathrm{O}\right)$ or with CT2-6His or CT2(e47)-6His. The expected molecular masses were $22 \mathrm{kDa}$ and $39 \mathrm{kDa}$ for CT2-6His and CT2(e47)-6His, respectively. NI, lysate obtained from non-injected oocytes. (c) Representative current traces recorded from $X$. laevis oocytes injected with the indicated $\operatorname{Cav} \alpha$ subunit with $\operatorname{Cav} \beta 4 \mathrm{a}$ and $\operatorname{Cav} \alpha 2 \delta 1$, alone or with CT2 or CT2(e47) (1:1:1:1 molar ratio). Currents were elicited by $400 \mathrm{~ms}-$ long step depolarizations 
from a holding potential of $-100 \mathrm{mV}$ to potentials between $-60 \mathrm{mV}$ and $+40 \mathrm{mV}$. Scale bars, 500 nA. (d) Current voltage curves (left), isochronal inactivation curves (middle), and R400 values (right) obtained for Cav2.1 alone, or with CT2-6His or CT2(e47)-6His. The parameters of both curves and the R400 values are similar or marginally affected (see Table 1). 
(a)

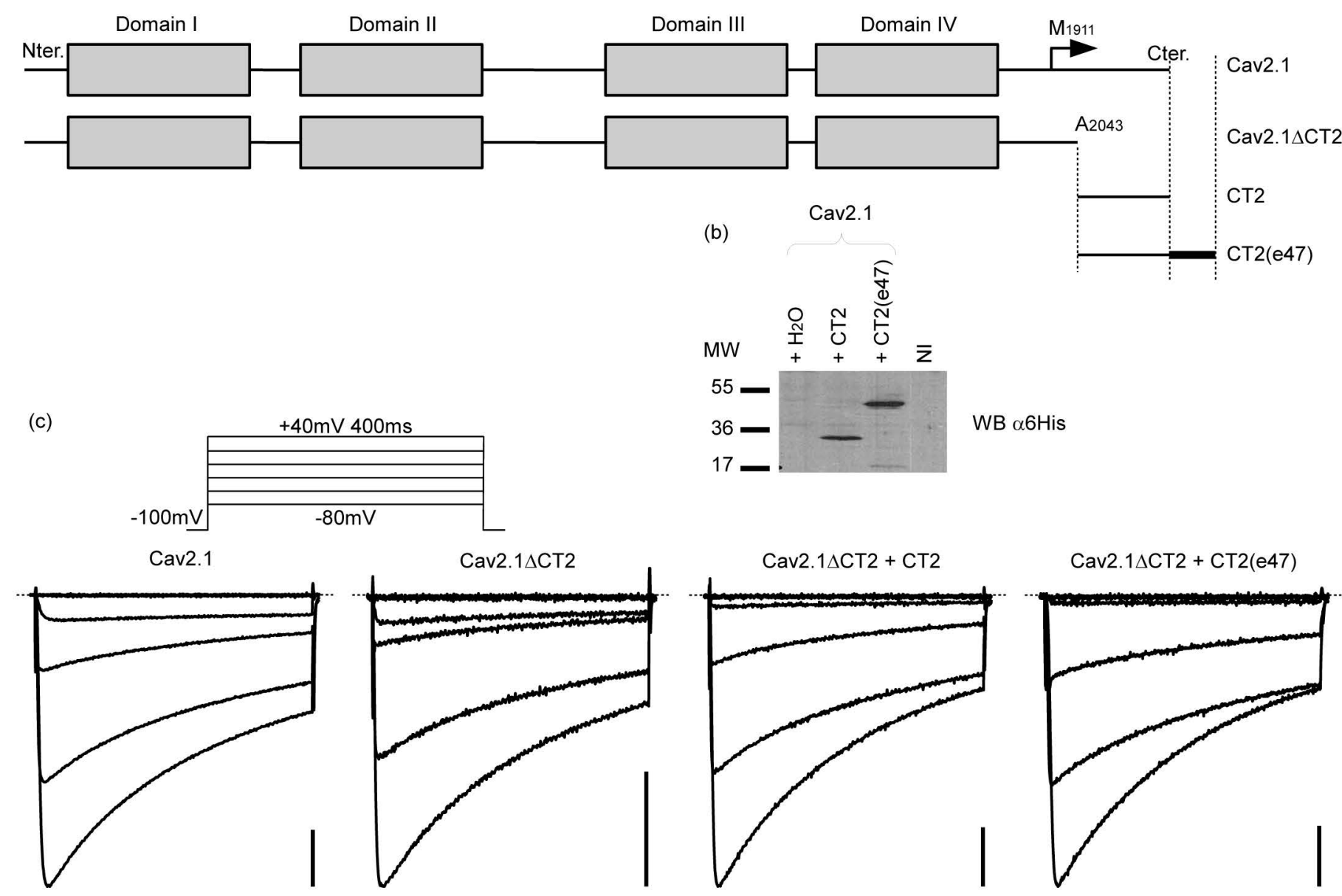

(d)

Membrane potential (mV)

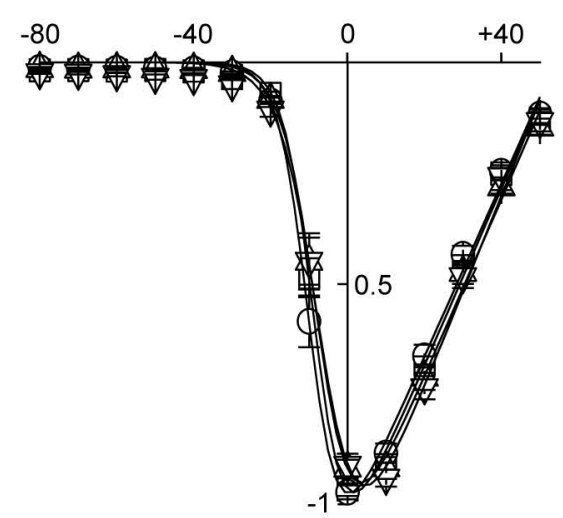

Relative amplitude
Cav2.1 $\triangle \mathrm{CT} 2+\mathrm{CT} 2(\mathrm{e} 47)$
Relative amplitude

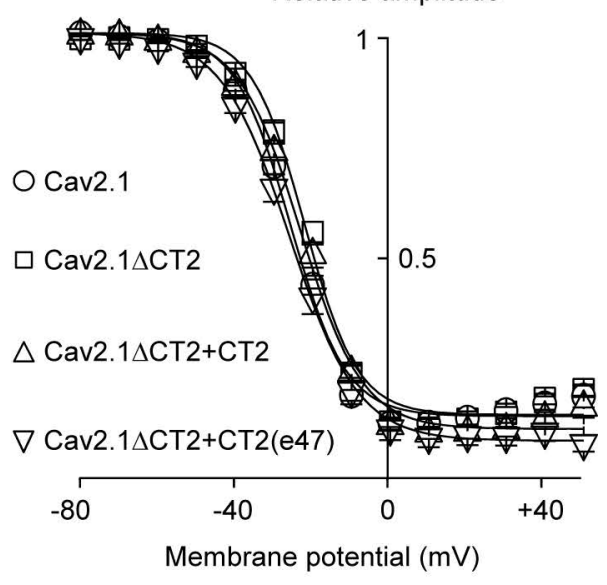

FIGURE 6

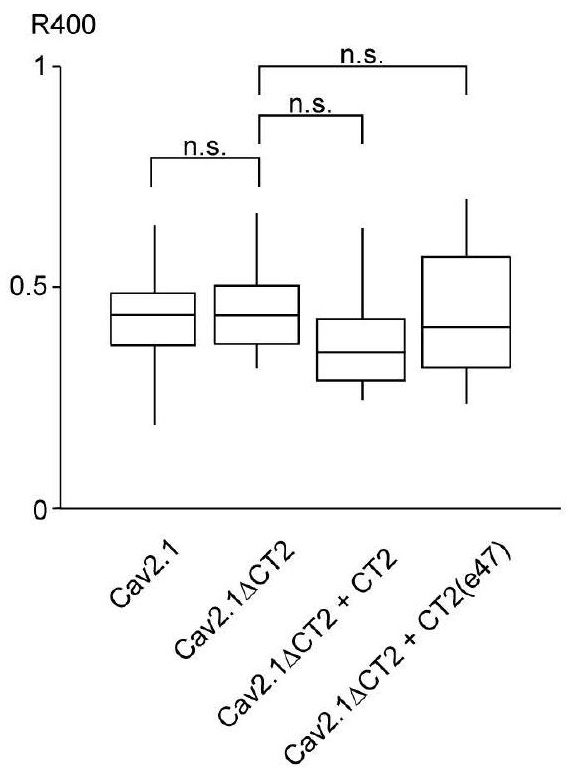


(a)

(a)

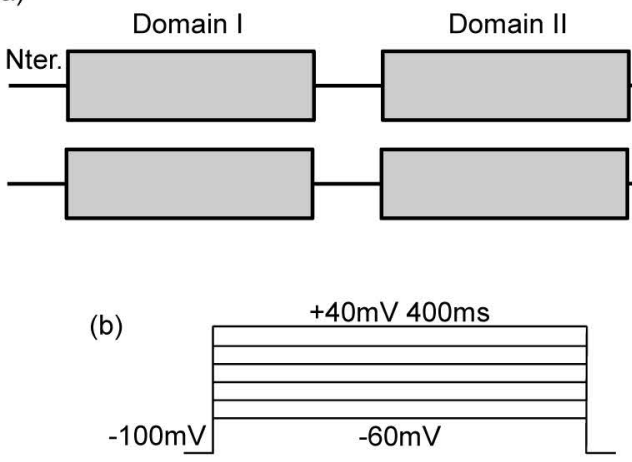

Domain III

Domain IV

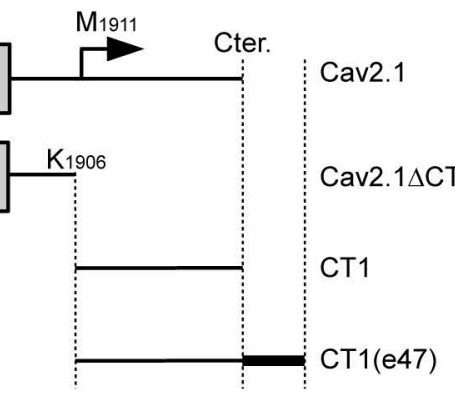

Cav2.1

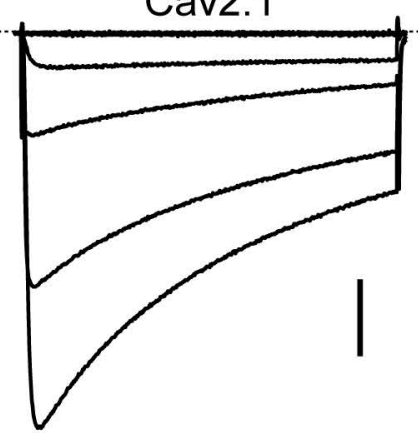

Cav2.1 $\triangle \mathrm{CT} 1$
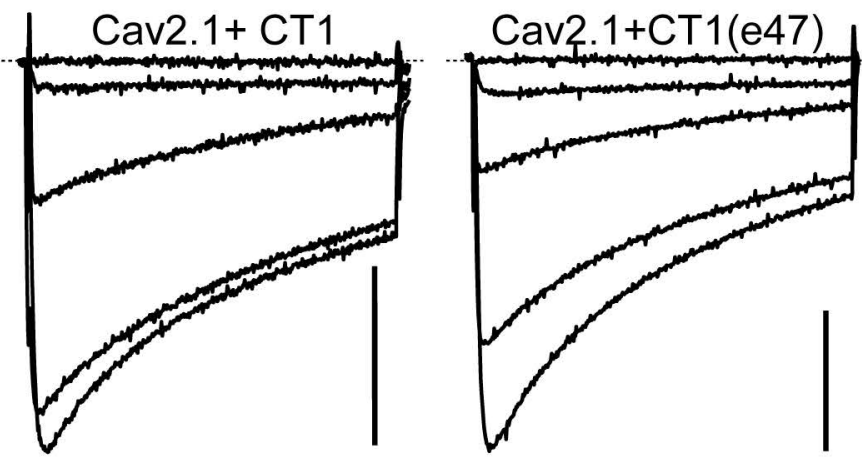

(c)

Membrane potential $(\mathrm{mV})$

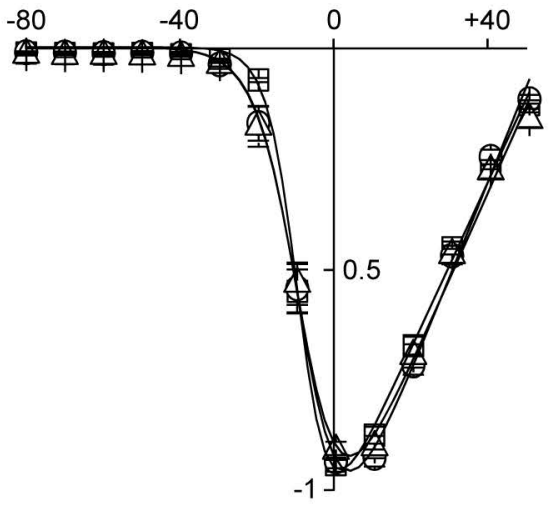

Relative amplitude

No expression

Relative amplitude

$\mathrm{R} 400$
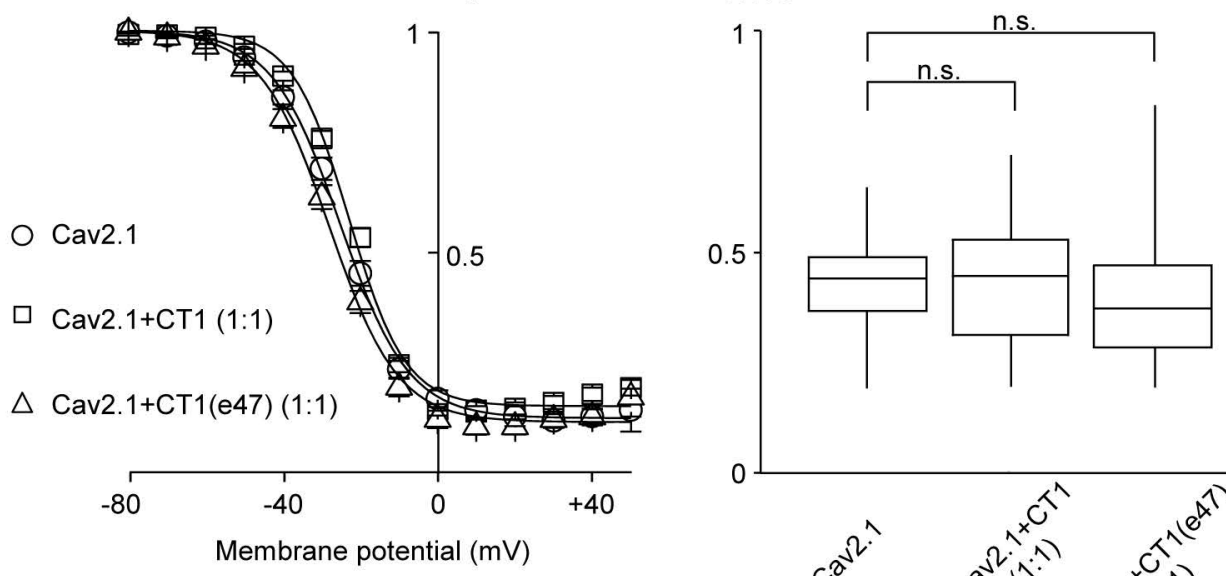

(d)

Cav2.1

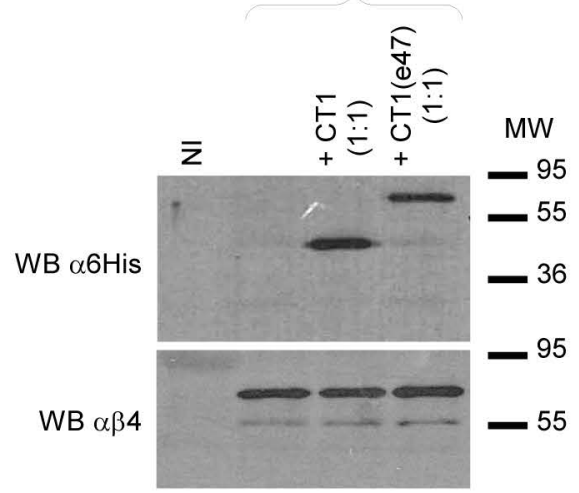

FIGURE 5 (e)

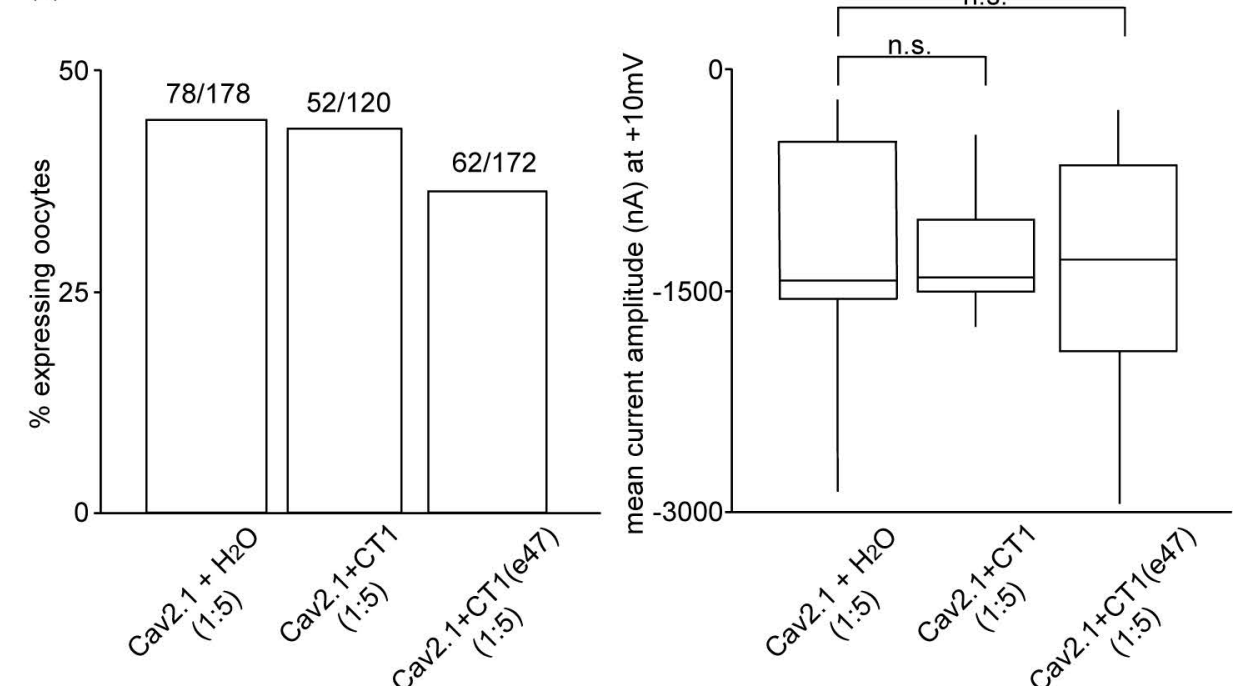




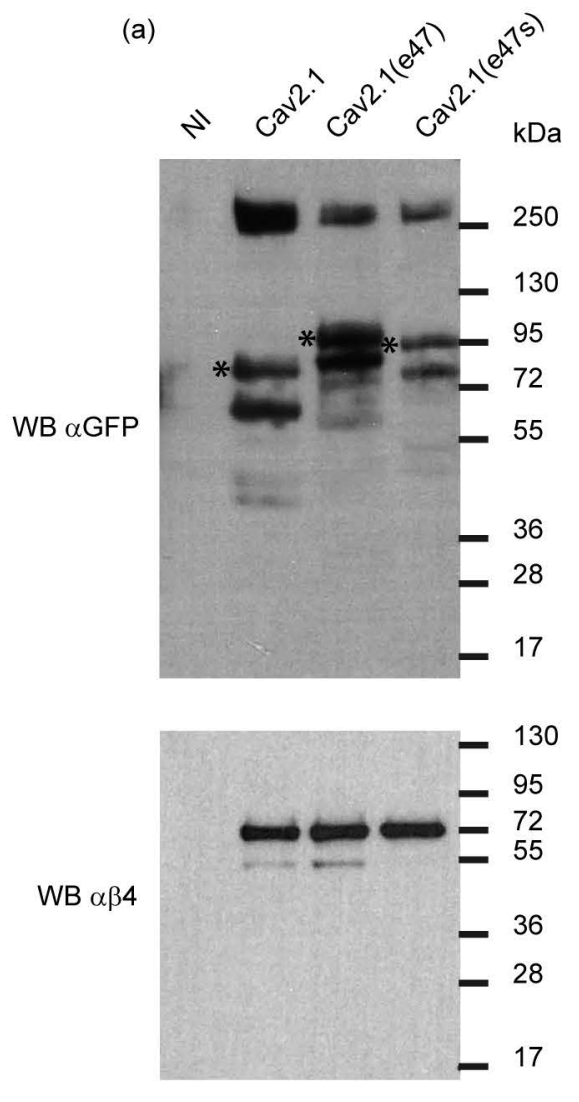

(b)

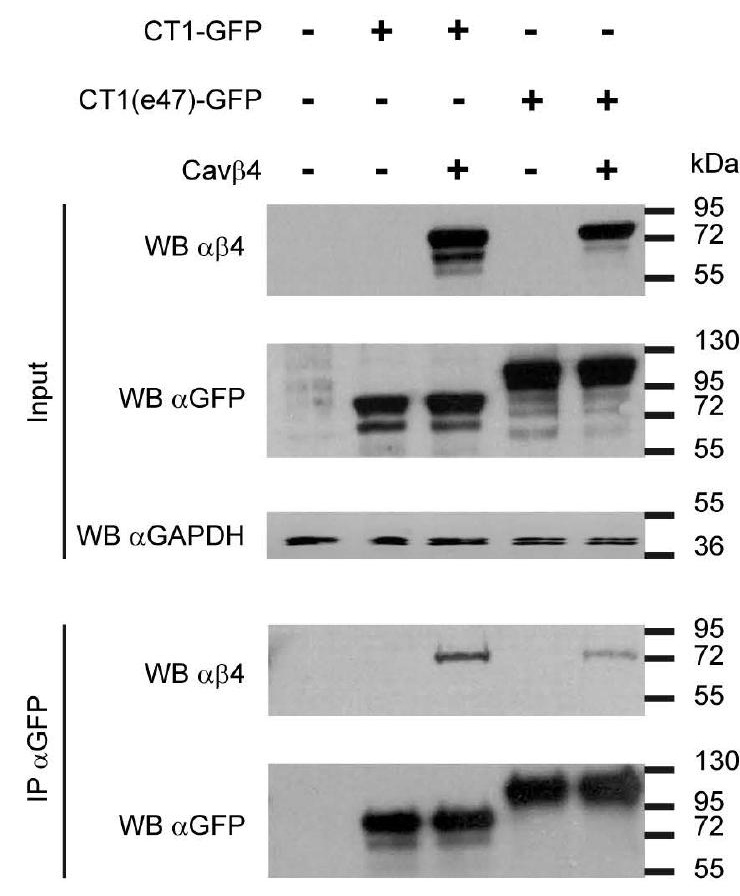

FIGURE 4 
(a)

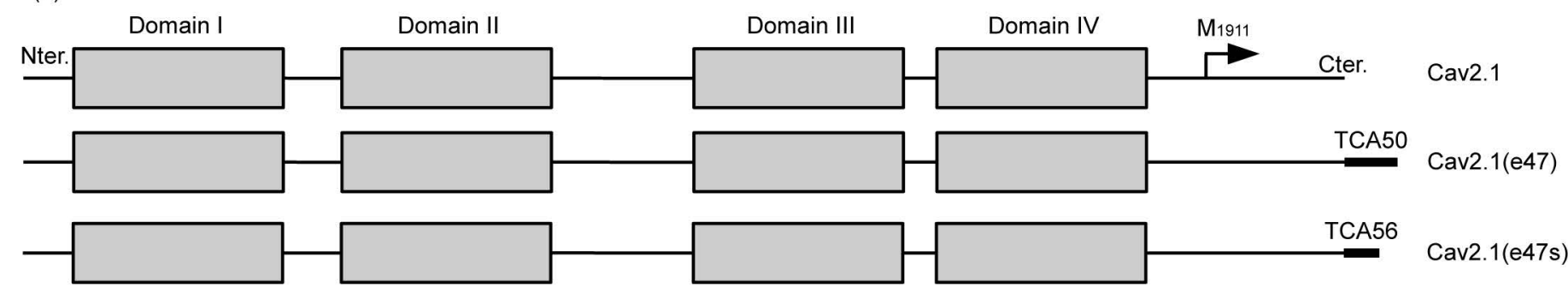

(b)

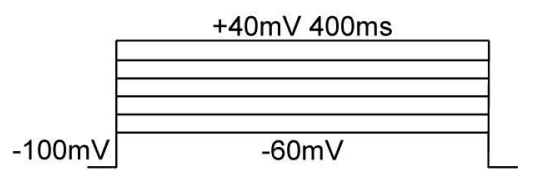

Cav2.1

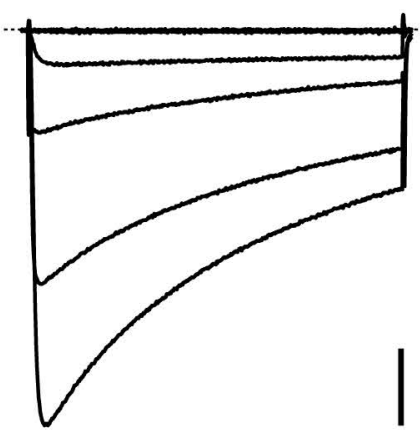

Cav2.1(e47)

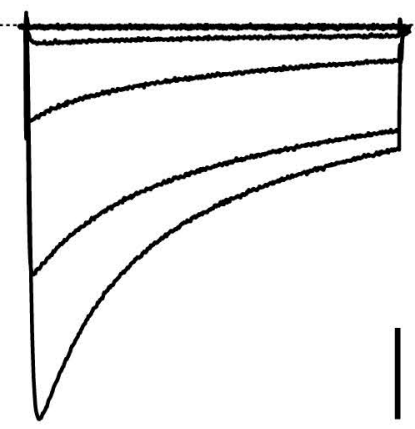

Cav2.1(e47s)

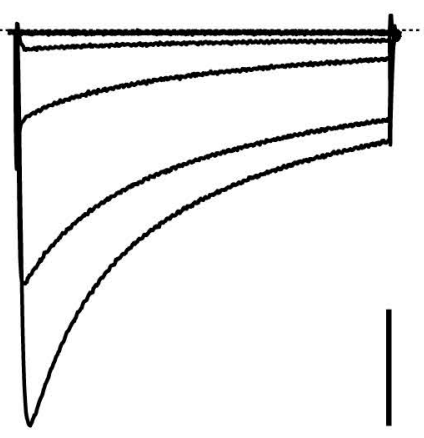

(c)

Membrane potential $(\mathrm{mV})$

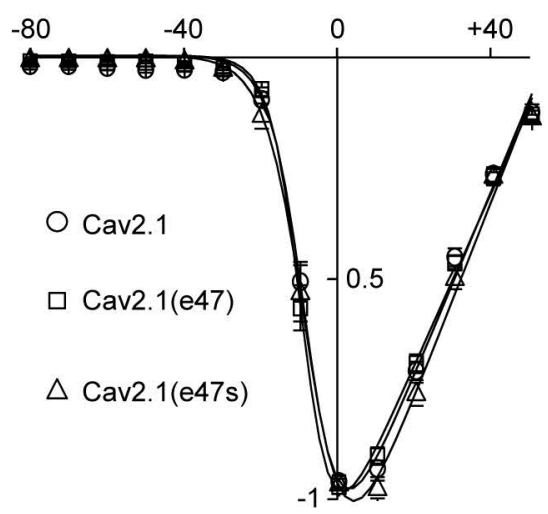

Relative amplitude

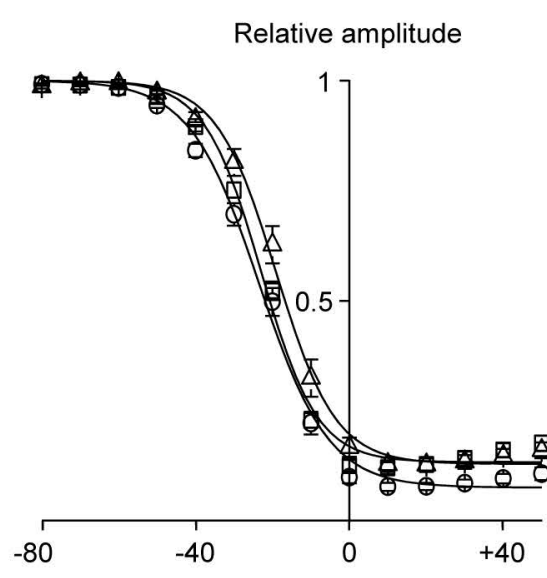

Membrane potential $(\mathrm{mV})$

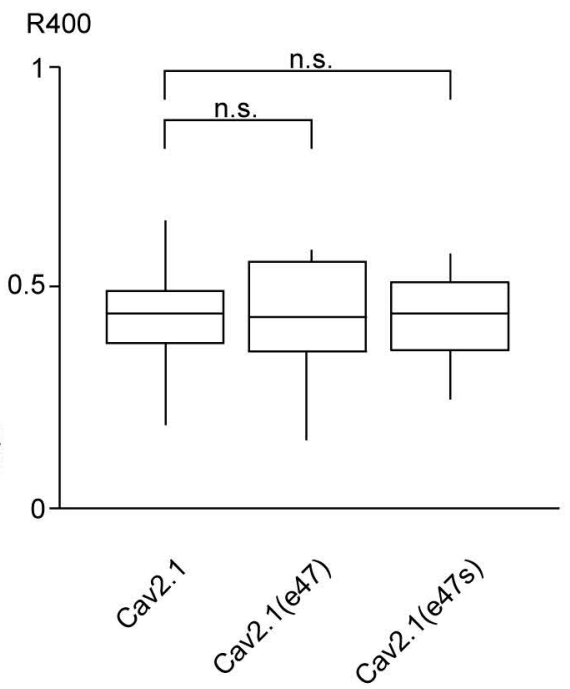

FIGURE 2 
(a)

\section{Exon 46}
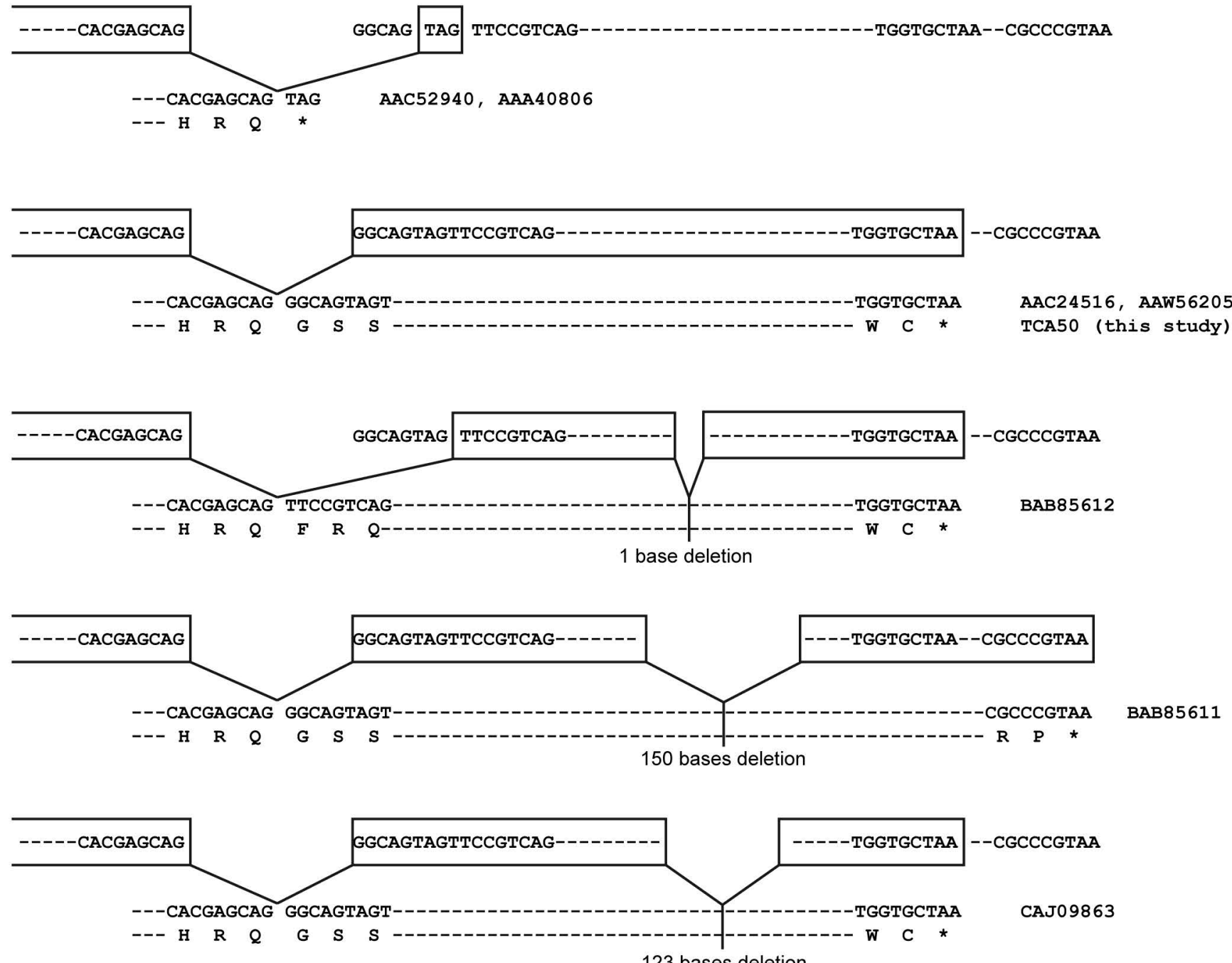

123 bases deletion

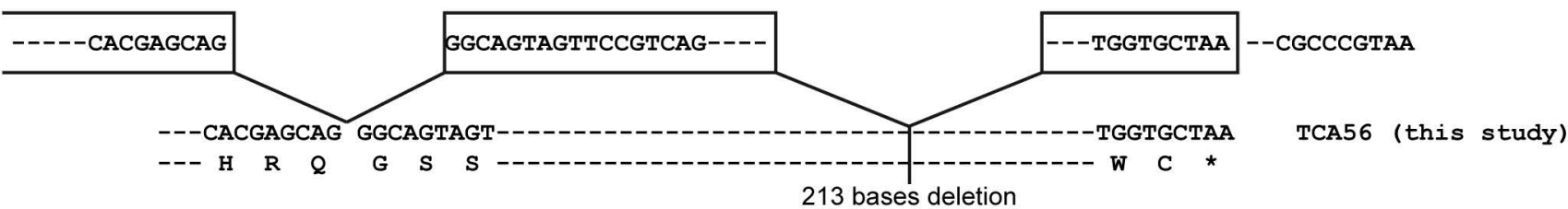

(b)

\section{Exon 46}

AAC52940 EGREHTTHRQ*

EGREHATHRQGSSSVSGSPAPSTSGTSTPRRGRROLPOTPCTPRPLVSYSPAPRRPAARRMAGPPAPPGGSPRGCRRAPRWPA

EGREHTTHRQ---FRQWKPSPLYVRHQHAAARPPPAPPDPLHPAAACVLLARSAQACGAQDGGSRSAPWRLAAGLPRAPRWPA 